\title{
Article \\ Characterization of Gamma-Rays-Induced Spring Wheat Mutants for Morphological and Quality Traits through Multivariate and GT Bi-Plot Analysis
}

\author{
Sana Zulfiqar ${ }^{1}$, Shumila Ishfaq ${ }^{1}$, Muhammad Ikram ${ }^{2}$, Muhammad Amjad Nawaz $^{3}(\mathbb{D}$ and \\ Mehboob-ur- Rahman ${ }^{1, *}$
}

check for

updates

Citation: Zulfiqar, S.; Ishfaq, S.; Ikram, M.; Nawaz, M.A.; Rahman, M.-u.- Characterization of

Gamma-Rays-Induced Spring Wheat Mutants for Morphological and Quality Traits through Multivariate and GT Bi-Plot Analysis. Agronomy 2021, 11, 0. https://doi.org/

Academic Editor: Ivan Ingelbrecht

Received: 17 July 2021

Accepted: 3 September 2021

Published: 15 September 2021

Publisher's Note: MDPI stays neutral with regard to jurisdictional claims in published maps and institutional affiliations.

Copyright: (c) 2021 by the authors. Licensee MDPI, Basel, Switzerland. This article is an open access article distributed under the terms and conditions of the Creative Commons Attribution (CC BY) license (https:/ / creativecommons.org/licenses/by/ $4.0 /)$.
1 Plant Genomics and Molecular Breeding Laboratory, National Institute for Biotechnology and Genetic Engineering College, Pakistan Institute of Engineering and Applied Sciences (NIBGE-C, PIEAS), Faisalabad 38000, Punjab, Pakistan; sanazulfiqar1132@gmail.com (S.Z.); shumilaishfaq2@gmail.com (S.I.)

2 School of Life Sciences, Guangzhou University, Guangzhou 510006, China; drikram@gzhu.edu.cn

3 Siberian Federal Scientific Center of Agrobiotechnology, Russian Academy of Sciences, Krasnoobsk 630501, Novosibirsk Region, Russia; amjad_ucauos@yahoo.com

* Correspondence: mehboob@nibge.org or mehboob_pbd@yahoo.com

\begin{abstract}
Exploiting new genetic resources is an effective way to achieve sustainable wheat production. To this end, we exposed wheat seeds of the "Punjab-11" cultivar to gamma rays. A total of 32 stable mutants $\left(\mathrm{M}_{7}\right)$ were developed, followed by characterization by conducting multilocation trials over two seasons. Principal component analysis (PCA) showed that the first six components accounted for $90.28 \%$ of the total variation among the plant height, tillers per plant, 1000-kernel weight, grain yield, and quality traits. All mutants were grouped into three clusters based on high yield index values. The genotype by trait (GT) bi-plot revealed significant associations between yield and its components among the mutants. Positive correlations were estimated for tillers per plant, plant height, 1000-kernel weight, and grain yield; however, yield components showed negative associations with protein, moisture, and gluten contents. The mutant lines $\mathrm{Pb}-\mathrm{M}-59$ waxy, $\mathrm{Pb}-\mathrm{M}-1272$ waxy, Pb-M-2260, Pb-M-1027 waxy, Pb-M-1323 waxy, and Pb-M-1854 exhibited maximum grain yield, 1000-grain weight, and tillers per plant values. Likewise, $\mathrm{Pb}-\mathrm{M}-2725, \mathrm{~Pb}-\mathrm{M}-2550$, and $\mathrm{Pb}-\mathrm{M}-2728$ were found to be the best mutant lines in terms of grain quality; thus, the use of gamma radiation is effective in improving the desirable traits, including yield and grain quality. It is suggested that these traits can be improved beyond the performance of corresponding traits in their parent genotypes. The newly produced mutants can also be used to explore the genetic mechanisms of complex traits in the future.
\end{abstract}

Keywords: Triticum aestivum L.; physical mutagen; phenotypic diversity; grain yield; quality traits; principal component analysis

\section{Introduction}

Spring wheat (Triticum aestivum L.), one of the major staple food crops, is grown worldwide over $\sim 222$ million hectares, with an annual production rate of 775.8 million tons [? ]. Other than starch, it is a rich source of proteins, vitamins, and dietary fibers, which are required to maintain a healthy diet [? ? ]. The present population growth rate demands sustained improvements in wheat production, particularly within the emerging context of climate change [? ? ? ]; hence, there is a dire need to explore new genetic solutions for sustainable wheat production [? ? ].

The existence of genetic variation within the germplasm ensures the development of improved wheat cultivars that can be grown under different agro-climatic conditions [? ]. Morphological traits provide the basis for the classification of genetic wheat sources [? ? ? ] Genetic diversity can be estimated using morphological traits, as well as molecular assays, 
including DNA fingerprinting and whole-genome sequencing. Phenotypic characterization procedures can be used to differentiate wheat genotypes in the field [? ]; therefore, the continuous development and availability of novel genetic resources are essential for improving wheat cultivars [? ? ].

The primary goal of a plant breeder is to develop cultivars with stable high yields and of better quality. The stability of a cultivar is a very important criterion for wheat breeders and molecular geneticists when exploring the diversity present in complex traits, such as grain yield and quality traits [? ? ]. Grain quality traits including protein contents are fundamental attributes of wheat quality. The variations in these traits are crucial for wheat improvement [? ]. Protein contents are estimated from the composition of gluten molecules, which are conferred via storage proteins in wheat grain [? ? ]. High protein and gluten contents are recognized as vital components in determining dough quality [? ]. The dominant protein in flour is gluten, which contributes 80 to $85 \%$ of the total proteins [? ]. Additionally, the grain moisture content plays an important role in determining wheat grain quality and is inversely related to dry matter loss [? ]. Grain yield is a complex trait and the prime objective of plant breeders is understanding the basis of associations (both genetic and phenotypic) among grain yield and other traits, which helps breeders in enhancing wheat production.

Multivariate analysis helps in the identification of groups of genotypes, accessions, or varieties containing the desirable trait combinations that are useful in plant breeding programs. Principal component analysis (PCA) and cluster analysis can be used to summarize and explain the variations among wheat genotypes [? ? ]. Principal component analysis can help in comprehending the variability present among the data by converting huge numbers of variables into smaller numbers, imparting sufficient information regarding genetic variation in the germplasm [? ]. This tool has been used to characterize different traits in several crop species, including heat and drought tolerance in wheat [? ? ? ], malting quality traits in barley [? ], genotypic origin in coffee [? ], drought tolerance in rice [? ? ], agro-morphological traits in sugar beet [? ], genetic diversity studies in sorghum [? ], and morphological traits in maize [? ]; therefore, the application of these statistical techniques will also be useful in delineating the variability in wheat genotypes and mutants.

A genotype by trait (GT) bi-plot assesses the GGE (main effect of a genotype, G) and its interaction with the environment (GE). The bi-plot technique has emerged as a potential tool that can be used to unravel the information about multiple traits simultaneously [? ]. Compared with multivariate analyses, the GT bi-plot tool characterizes genotypes based on multiple traits and helps in the identification of superior genotypes possessing desirable combinations of variables, ultimately leading toward their utilization in crop breeding programs as commercial cultivars or even parents [? ]. The GT bi-plot analysis can also be used to demonstrate the genetic associations among multiple traits [? ? ]. Furthermore, valuable information about the efficient utilization of genotypes for production, for the identification of less desirable traits, and as the basis for indirect selection of target traits by identifying suitable features can be explored with this approach [? ]. Since it was first reported by Gabriel [? ], this approach has been applied to data from different crops to understand the effects of the genotype and environment on the relationships between agronomic, physiological, quality, and yield characteristics [? ? ? ? ? ? ? ? ].

Knowledge of the genetic variability regarding morphological and quality traits is essential in achieving the goals of wheat breeding programs, including achieving high yield, wider adaptability, and desirable quality attributes [? ]; therefore, we planned this experiment to study the mutagenic effects of gamma radiation on grain yield in terms of the performance, stability, and bread wheat quality of the "Punjab-11" variety. We also attempted to classify the bread wheat mutant lines into various groups, followed by the identification of genetically diverse mutants possessing desirable grain yield and yield components. 
In the present study, 32 mutant lines and a wild type wheat cultivar "Punjab-11" were selected from the already developed $\mathrm{M}_{5}$ gamma-radiated mutant population. Variation patterns among wheat mutant lines were studied through PCA and GT bi-plot analyses. This study will provide insights into the genetic advances made in terms of the grain yield and quality of the selected mutants, and could be potential help in identifying mutant lines that can be utilized in future wheat breeding programs.

\section{Materials and Methods}

\subsection{Mutant Population Development}

Breeder seeds of Punjab-11 were treated with an optimized dose of gamma radiation (Cs 137 (250 k Gy)) for a duration of $25 \mathrm{~min}$ at ambient room temperature to induce mutagenesis. For surface sterilization, seeds were treated with sodium hypochlorite $(5 \%)$ and ethanol $(70 \%)$ followed by three to five washings with distilled water.

In total, 7000 seeds of the wheat variety "Punjab-11" were treated with an optimum dose of gamma radiation. The $\mathrm{M}_{0}$ seeds of the parent Punjab-11 were grown at the field station at NIBGE, Pakistan, during 2012. We kept the rows $30 \mathrm{~cm}$ apart from each other, while the seeds were sown at $10 \mathrm{~cm}$ apart in each row. In total, $3700 \mathrm{M}_{1}$ plants were germinated. Standard cultural practices were provided from sowing until harvesting. We bagged the spike of the main tiller of each plant to avoid cross pollination. The main spike from each $\mathrm{M}_{1}$ plant was then harvested and threshed separately followed by sowing of the $\mathrm{M}_{2}$ rows in 2013. In the next year (2014), the $\mathrm{M}_{3}$ row of each $\mathrm{M}_{2}$ plant was sown, followed by harvesting a single main spike from the first plant of each row. Then, $\mathrm{M}_{4}$ was sown in the off season for generation advancement. Next, a whole single plant containing 3-5 tillers was harvested separately and sown during 2015 to enable sowing of $\mathrm{M}_{5}$ rows. Again, the first single plant containing 3-5 tillers was harvested from each row. In 2016-2017, 3483 $\mathrm{M}_{6}$ families were planted in the field at NIBGE. At this stage, almost all mutant families exhibited homozygosity and uniformity. Out of these, a total of 32 stable mutant lines were selected based on their responses to rust diseases.

\subsection{Experimental Design}

The experiment was conducted at two locations, i.e., field stations of the National Institute for Biotechnology and Genetic Engineering (NIBGE) and Nuclear Institute for Agriculture and Biology (NIAB), during normal wheat growing seasons over the period 2018-2020. The field experiments were conducted by adopting a randomized complete block design (RCBD) using three replications for both the locations and years. Two-season testing was carried out to evaluate the genetic stability of the traits under field conditions. The distance between the rows and plants was kept to $30 \mathrm{~cm}$ and $10 \mathrm{~cm}$, respectively. For each hill, only one plant was retained by removing the extra plants at the seedling stage. For collection of data, five plants were tagged in each row. Recommended fertilizers were applied, including urea $(100 \mathrm{~kg})$, phosphate (DAP) $(100 \mathrm{~kg})$, and potash $(50 \mathrm{~kg})$. Both potash and phosphate along with urea $(50 \mathrm{~kg})$ were applied at the time of sowing. In addition, the remaining urea was applied during the first and second irrigation stages (25:25 kg). Weeds were controlled by applying two sprays, namely Bromoxinal ( $300 \mathrm{~mL} /$ acre) after the first irrigation and Topik (100 g) after the second irrigation. The recommended agronomic practices were carried out from sowing until harvesting [? ].

\subsection{Data Collection}

Data of different morphological traits such as plant height, number of tillers per plant, number of days to heading, spike length, number of spikelets per spike, 1000-kernel weight, and grain yield were recorded. The numbers of days to flowering were counted after the emergence of $50 \%$ heads. The plant height $(\mathrm{cm})$ of each tagged plant was measured form the base of the plant to the tip of the spike using a meter stick. The spike length was also measured from the bottom to the spike tip without awns. Additionally, number of tillers per plant and number of spikelets per spike were counted at maturity. To measure the 
1000-kernel weight, 1000 seeds of each mutant line were weighed using an electric balance (VWR ${ }^{\circledR}$ A-Series balances). The grain yield of each mutant line and wild type was also measured. Lastly, important seed quality attributes such as the protein, moisture, and gluten contents were estimated through OmegAnalyzer.

\subsection{Statistical Analyses}

Analysis of variance (ANOVA) [? ] was performed for each trait for all generations to determine the extent of variation and significance among the mutant lines using SPSS16 software. The probability levels were kept to $1 \%$ and $5 \%$ to test the statistical levels of significance. Furthermore, minimum differences among the mean values were estimated via the least significant difference (LSD) test [? ].

The PCA and cluster analyses were performed using NCSS 2020 software. Principal Component Analysis values were used to construct a dendrogram based on the Euclidean distance matrix. The mutant lines were grouped according to the Ward's minimum variance method [? ]. Additionally, GT bi-plot analysis was performed for estimation of the degrees of association among traits and mutant lines and for the identification of suitable mutant lines with desirable trait combinations using the GGE bi-plot tool [? ].

\section{Results}

\subsection{ANOVA and Descriptive Assessment}

Highly significant differences were found for plant height, days to heading, and yield-related traits from the experimental fields sown at NIBGE (Table ??) and NIAB sites (Table ??) at $p<0.001$. Genotypic variance declined gradually during successive generations. Furthermore, box plots also revealed variation for the studied traits in both generations $\left(\mathrm{M}_{7}-\mathrm{M}_{8}\right)$ (???????).
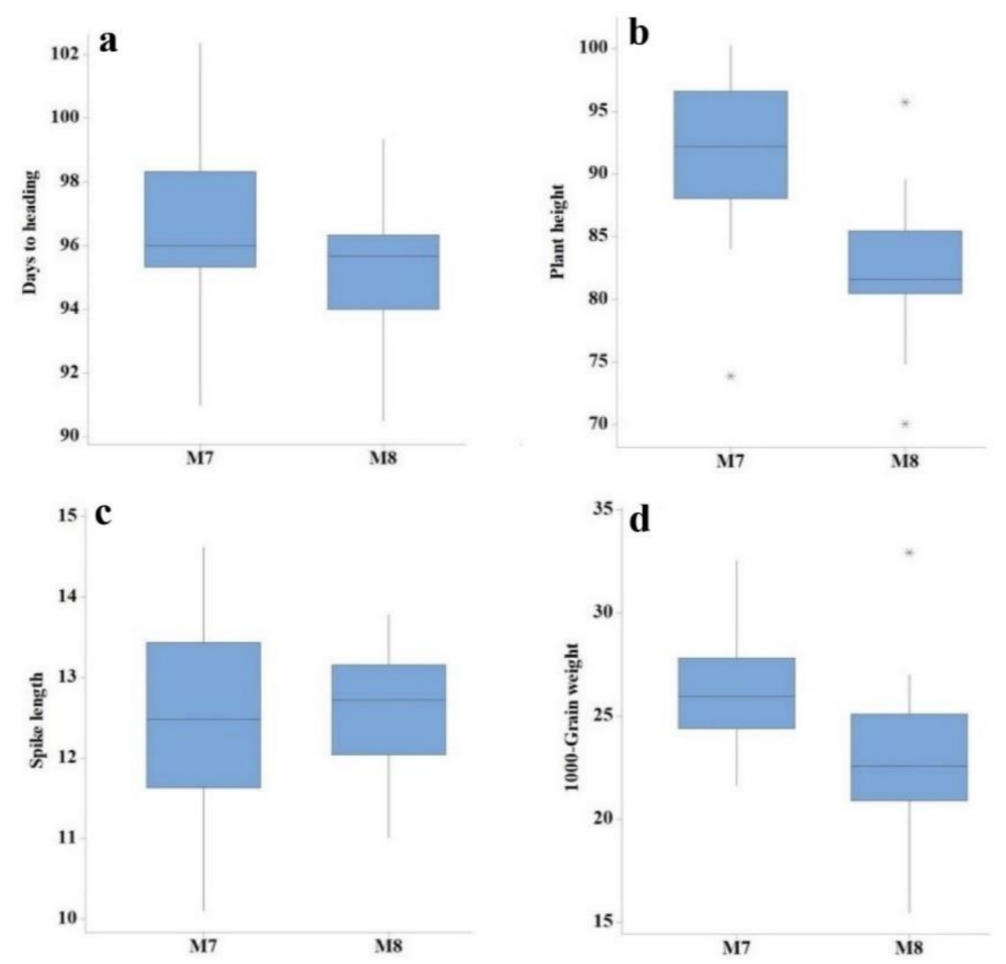

Figure 1. Boxplots showing median, minimum, maximum, and mean values (a) days to heading; (b) plant height; (c) spike length; (d) 1000-grain weight at the NIBGE location; * represents outliers. 

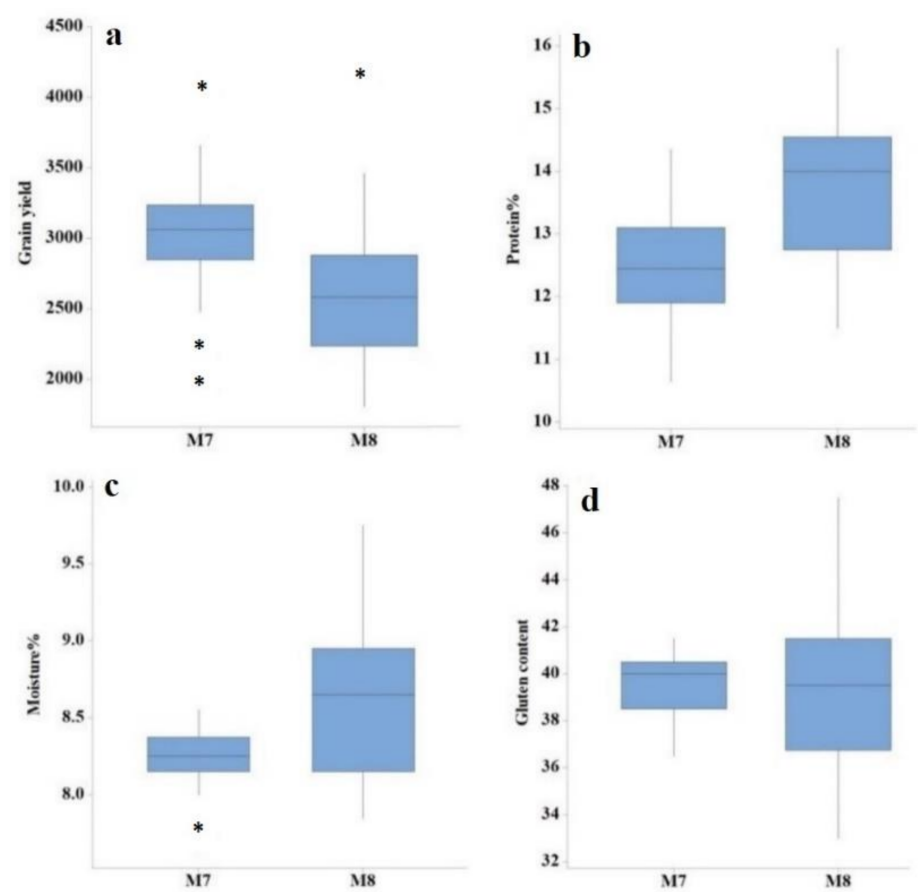

Figure 2. Box plots showing median, minimum, maximum, and mean values: (a) grain yield; (b) $\operatorname{protein} \%$; (c) moisture\%; (d) gluten content at NIBGE location; * represents outliers.
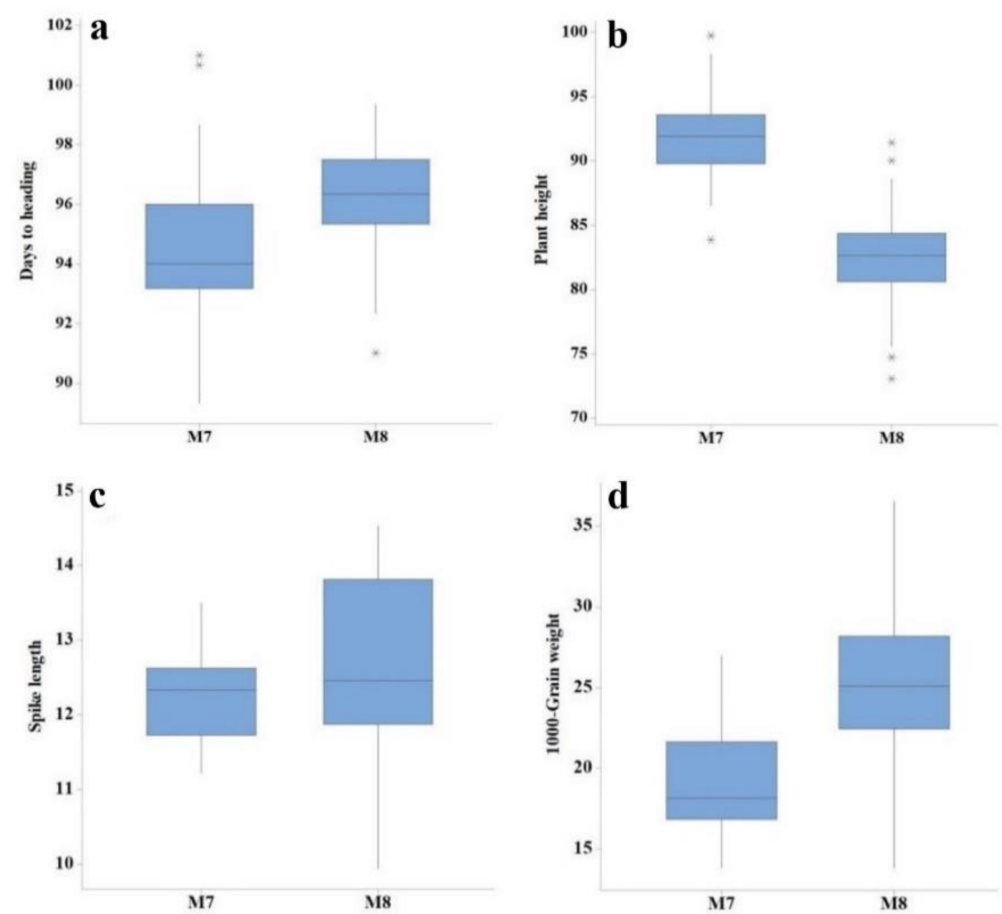

Figure 3. Boxplots showing the median, minimum, maximum, and mean values: (a) days to heading; (b) plant height; (c) spike length; (d) 1000-grain weight at the NIAB location; * represents outliers. 


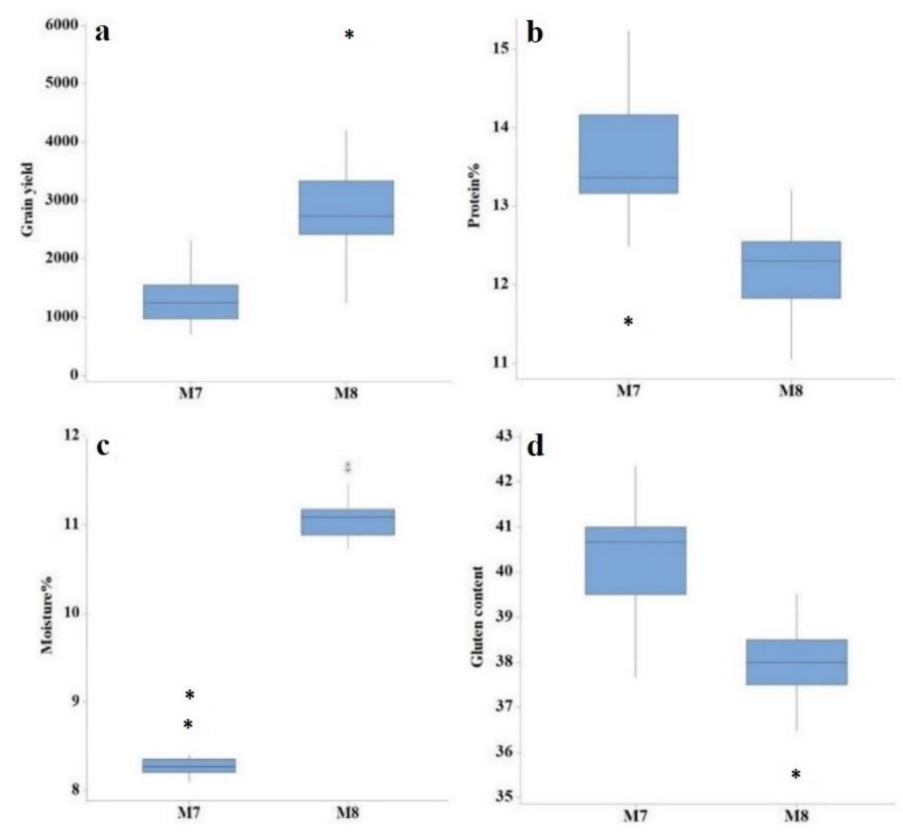

Figure 4. Box plot showing median, minimum, maximum, and mean values: (a) grain yield; (b) protein \%; (c) moisture\%; (d) gluten content at the NIAB location; * represents outliers.

\subsection{Mean Values for Various Yield Components, Grain Yield, and Quality Traits}

Significant variation was recorded among all mutant lines and the wild type for yield component, total yield, and grain quality parameters. At location NIBGE, the numbers of days to heading ranged from 91 to 102 for the $M_{7}$ generation, while for the $M_{8}$ generation it ranged from 91 to 99 days. Plant heights varied between 73.90 and $100.64 \mathrm{~cm}$ for the $\mathrm{M}_{7}$ generation, however, while a wide range of 70.04 to $89.52 \mathrm{~cm}$ was observed in $\mathrm{M}_{8}$. Spike lengths ranged from 10.10 to $14.62 \mathrm{~cm}$ in the $\mathrm{M}_{7}$ generation. Similar variation patterns were also obtained regarding other yield related parameters in both generations. Regarding grain quality traits, protein percentages varied between 10.65 and $14.35 \%$ in $\mathrm{M}_{7}$. Considerable amounts of variation were also recorded for moisture and gluten content (Table ??); hence, the studied mutant lines expressed genetic variation for all traits under study. These mutant lines could be explored in future wheat breeding programs.

Table 1. Mean square values for all traits of 32 mutant lines and the wild type in $M_{7}$ and $M_{8}$ generations at the NIBGE location.

\begin{tabular}{|c|c|c|c|c|}
\hline Generations & Trait & Genotypes & Error & Total \\
\hline & Df & 64 & 32 & 98 \\
\hline \multirow{11}{*}{$\mathrm{M}_{7}$} & Days to heading & $19.05^{* *}$ & 2.79 & 24.11 \\
\hline & Plant height & $99.65^{* *}$ & 6.61 & 107.30 \\
\hline & Tillers per plant & $1.56^{* *}$ & 0.39 & 4.50 \\
\hline & Spike length & $4.41^{* *}$ & 42.95 & 47.73 \\
\hline & Number of spikelets per spike & $4.79 * *$ & 2.06 & 7.62 \\
\hline & 1000-grain weight & $21.13 * *$ & 2.51 & 44.95 \\
\hline & Grain yield & $510,874 * *$ & 30,347 & 614,024 \\
\hline & Df & 32 & 33 & 65 \\
\hline & Protein content & $1.45^{* *}$ & 0.01 & 1.45 \\
\hline & Moisture content & $0.07^{* *}$ & 0.01 & 0.15 \\
\hline & Gluten content & $3.15^{* *}$ & 0.35 & 7.88 \\
\hline
\end{tabular}


Table 1. Cont.

\begin{tabular}{ccccc}
\hline & Df & 64 & 32 & 98 \\
\hline & Days to heading & $11.95^{* *}$ & 0.03 & 12.07 \\
\cline { 2 - 5 } & Plant height & $53.72^{* *}$ & 1.90 & 58.65 \\
\cline { 2 - 5 } & Tillers per plant & $0.96^{* *}$ & 0.63 & 2.17 \\
\cline { 2 - 5 } $\mathrm{M}_{8}$ Spike length & $1.86^{* *}$ & 1.34 & 3.41 \\
\cline { 2 - 5 } & $2.06^{* *}$ & 1.44 & 5.48 \\
\cline { 2 - 5 } & Number of spikelets per spike & $35.34^{* *}$ & 0.35 & 36.31 \\
\cline { 2 - 5 } & 1000-grain weight & $358,408^{* *}$ & 10,662 & 969,070 \\
\cline { 2 - 5 } & Grain yield & $3.69^{* *}$ & 1.25 & 3.95 \\
\cline { 2 - 4 } & Protein content & $0.50^{* *}$ & 0.33 & 0.83 \\
\cline { 2 - 4 } & Moisture content & $21.05^{* *}$ & 7.59 & 28.61 \\
\hline Gluten content & &
\end{tabular}

Df denotes the degree of freedom, ${ }^{* *}$ indicates $p$-value $<0.01$.

Table 2. Mean square values of all traits calculated for 32 mutant lines and the wild type in $\mathrm{M}_{7}$ and $\mathrm{M}_{8}$ generations at the NIAB location.

\begin{tabular}{|c|c|c|c|c|}
\hline Generations & Trait & Genotypes & Error & Total \\
\hline \multirow{13}{*}{$\mathrm{M}_{7}$} & Df & 32 & 64 & 98 \\
\hline & Days to heading & $20.04^{* *}$ & 5.85 & 59.36 \\
\hline & Plant height & $34.19 * *$ & 6.65 & 69.37 \\
\hline & Tillers per plant & $0.54^{* *}$ & 0.34 & 0.89 \\
\hline & Spike length & $1.02 * *$ & 0.75 & 10.40 \\
\hline & Number of spikelets per spike & $2.68 * *$ & 1.89 & 14.75 \\
\hline & 1000-grain weight & $34.14^{* *}$ & 2.03 & 46.33 \\
\hline & Grain yield & $585,260 * *$ & 27,621 & 624,181 \\
\hline & Df & 32 & 33 & 65 \\
\hline & Protein content & $1.30^{* *}$ & 0.03 & 1.33 \\
\hline & Moisture content & $0.087^{* *}$ & 0.01 & 0.10 \\
\hline & Gluten content & $2.57 * *$ & 0.20 & 2.76 \\
\hline & Df & 64 & 32 & 98 \\
\hline \multirow{11}{*}{$\mathrm{M}_{8}$} & Days to heading & $10.81^{* *}$ & 0.52 & 14.29 \\
\hline & Plant height & $49.14^{* *}$ & 1.51 & 54.85 \\
\hline & Tillers per plant & $0.35^{* *}$ & 0.32 & 1.05 \\
\hline & Spike length & $4.55^{* *}$ & 0.35 & 5.09 \\
\hline & Number of Spikelets per spike & $2.15^{* *}$ & 1.41 & 5.14 \\
\hline & 1000-grain weight & $67.35 * *$ & 0.30 & 68.04 \\
\hline & Grain yield & $2,111,692 * *$ & 1977 & $2,113,669$ \\
\hline & Df & 32 & 33 & 65 \\
\hline & Protein content & $0.44^{* *}$ & 0.02 & 0.46 \\
\hline & Moisture content & $0.18^{* *}$ & 0.01 & 0.19 \\
\hline & Gluten content & $1.85^{* *}$ & 0.52 & 2.36 \\
\hline
\end{tabular}

Df denotes the degree of freedom, ${ }^{* *}$ indicates $p$-value $<0.01$. 
Table 3. Descriptive statistics of all traits calculated for 32 mutant lines and the wild type in $\mathrm{M}_{7}$ and $\mathrm{M}_{8}$ generations at the NIBGE location.

\begin{tabular}{|c|c|c|c|c|c|c|c|}
\hline Generation & Trait & Min & $\operatorname{Max}$ & Mean & SD & CV $(\%)$ & LSD \\
\hline \multirow{10}{*}{$\mathrm{M}_{7}$} & Days to heading & 91.00 & 102.00 & 96.87 & 2.51 & 1.73 & 2.73 \\
\hline & Plant height $(\mathrm{cm})$ & 73.90 & 100.64 & 91.99 & 5.76 & 2.79 & 4.19 \\
\hline & Tillers per plant & 4.00 & 7.00 & 5.30 & 0.73 & 12.25 & 1.02 \\
\hline & Spike length (cm) & 10.10 & 14.62 & 12.49 & 1.21 & 6.56 & 1.34 \\
\hline & $\begin{array}{c}\text { Number of spikelets per } \\
\text { spike }\end{array}$ & 15.00 & 21.00 & 18.52 & 1.73 & 7.74 & 2.34 \\
\hline & 1000-grain weight & 21.65 & 32.52 & 26.23 & 2.65 & 6.05 & 1.29 \\
\hline & Grain yield (kg/ha) & 2026.30 & 4098.40 & 3041.30 & 412.66 & 5.73 & 284.15 \\
\hline & Protein content (\%) & 10.65 & 14.35 & 12.46 & 0.84 & 0.95 & 0.24 \\
\hline & Moisture content (\%) & 7.65 & 8.55 & 8.25 & 0.19 & 1.02 & 0.17 \\
\hline & Gluten content & 37.00 & 42.00 & 39.87 & 1.32 & 1.49 & 1.20 \\
\hline \multirow{10}{*}{$\mathrm{M}_{8}$} & Days to heading & 91.00 & 99.00 & 95.24 & 1.95 & 0.18 & 0.27 \\
\hline & Plant height $(\mathrm{cm})$ & 70.04 & 89.52 & 81.92 & 4.23 & 1.68 & 2.25 \\
\hline & Tillers per plant & 5.00 & 7.00 & 6.06 & 0.61 & 12.92 & 1.30 \\
\hline & Spike length $(\mathrm{cm})$ & 11.01 & 13.78 & 12.53 & 0.79 & 9.23 & 1.89 \\
\hline & $\begin{array}{l}\text { Number of spikelets per } \\
\text { spike }\end{array}$ & 15.00 & 19.00 & 17.85 & 1.12 & 6.82 & 1.96 \\
\hline & 1000-grain weight & 15.49 & 32.93 & 22.86 & 3.43 & 2.59 & 0.96 \\
\hline & Grain yield (kg/ha) & 1806.30 & 4183.30 & 2592.50 & 534.91 & 4.66 & 168.43 \\
\hline & Protein content $(\%)$ & 11.50 & 15.95 & 13.79 & 1.16 & 8.12 & 2.28 \\
\hline & Moisture content (\%) & 7.85 & 9.75 & 8.61 & 0.49 & 6.86 & 1.16 \\
\hline & Gluten content & 33.00 & 48.00 & 39.61 & 3.30 & 7.00 & 5.61 \\
\hline
\end{tabular}

Min: minimum; Max: maximum; SD: standard deviation; CV: coefficient of variation; LSD: least significant difference.

At the NIAB location, the numbers of days to heading ranged from 89 to 101 for $\mathrm{M}_{7}$, while for the $\mathrm{M}_{8}$ generation it ranged from 91 to 99 days. Plant heights varied from 83.87 to $99.74 \mathrm{~cm}$ for the $\mathrm{M}_{7}$ generation; however, during $\mathrm{M}_{8}$, a wider range $(73.02-91.44 \mathrm{~cm}$ ) was measured. Spike lengths ranged from 11.22 to $13.50 \mathrm{~cm}$ in the $\mathrm{M}_{7}$ generation (Table ??). Similar variation patterns were observed for other yield components. For grain quality traits substantial differences among all the mutants and wild type were observed for both generations $\left(\mathrm{M}_{7}\right.$ and $\left.\mathrm{M}_{8}\right)$. In $\mathrm{M}_{7}$, the protein content percentages varied between $11.50 \%$ and $15.95 \%$. Significant variations were also observed in moisture and gluten contents for both generations (Table ??). 
Table 4. Descriptive statistics of all traits calculated for 32 mutant lines and the wild type in $\mathrm{M}_{7}$ and $\mathrm{M}_{8}$ generations at the NIAB location.

\begin{tabular}{|c|c|c|c|c|c|c|c|}
\hline Generation & Trait & Min & Max & Mean & SD & CV $(\%)$ & LSD \\
\hline \multirow{10}{*}{$\mathrm{M}_{7}$} & Days to heading & 89.00 & 101.00 & 94.52 & 2.65 & 2.56 & 2.73 \\
\hline & Plant height $(\mathrm{cm})$ & 83.87 & 99.74 & 91.67 & 3.38 & 2.81 & 4.19 \\
\hline & Tillers per plant & 4.00 & 6.00 & 4.64 & 0.60 & 12.50 & 1.02 \\
\hline & Spike length $(\mathrm{cm})$ & 11.22 & 13.50 & 12.27 & 0.58 & 7.04 & 1.34 \\
\hline & $\begin{array}{l}\text { Number of spikelets per } \\
\text { spike }\end{array}$ & 17.00 & 21.00 & 19.00 & 1.50 & 7.38 & 2.34 \\
\hline & 1000-grain weight & 13.83 & 26.95 & 19.08 & 3.27 & 7.47 & 2.59 \\
\hline & Grain yield (kg/ha) & 717.86 & 2309.40 & 1343.60 & 441.69 & 12.37 & 284.15 \\
\hline & Protein content $(\%)$ & 11.53 & 15.23 & 13.57 & 0.81 & 1.21 & 0.33 \\
\hline & Moisture content (\%) & 8.10 & 8.87 & 8.32 & 0.18 & 1.08 & 0.18 \\
\hline & Gluten content & 37.67 & 42.33 & 40.29 & 1.02 & 1.10 & 0.90 \\
\hline \multirow{10}{*}{$\mathrm{M}_{8}$} & Days to heading & 91.00 & 99.00 & 96.09 & 1.89 & 0.75 & 1.18 \\
\hline & Plant height $(\mathrm{cm})$ & 73.02 & 91.44 & 82.89 & 4.05 & 1.58 & 2.00 \\
\hline & Tillers per plant & 6.00 & 7.00 & 6.61 & 0.50 & 8.68 & 0.93 \\
\hline & Spike length (cm) & 9.94 & 14.54 & 12.68 & 1.23 & 4.69 & 0.97 \\
\hline & $\begin{array}{c}\text { Number of spikelets per } \\
\text { spike }\end{array}$ & 17.00 & 21.00 & 19.30 & 1.42 & 6.33 & 1.94 \\
\hline & 1000-grain weight & 13.85 & 36.55 & 25.47 & 4.74 & 2.14 & 0.89 \\
\hline & Grain yield (kg/ha) & 1244.50 & 5819.10 & 2951.20 & 838.39 & 5.49 & 72.52 \\
\hline & Protein content (\%) & 11.05 & 13.20 & 12.26 & 0.47 & 1.10 & 0.27 \\
\hline & Moisture content (\%) & 10.73 & 11.68 & 11.07 & 0.24 & 1.10 & 0.23 \\
\hline & Gluten content & 36.00 & 40.00 & 38.36 & 0.96 & 1.89 & 1.46 \\
\hline
\end{tabular}

Min: minimum; Max: maximum; SD: standard deviation; CV: coefficient of variation; LSD: least significant difference.

\subsection{Mean Evaluation of Mutant Lines across Both Locations and Generations}

The mean values of all traits under study for the selected 32 mutant lines and the wild type (Punjab-11) over two growing seasons and locations are presented in Table ??. The numbers of days to heading significantly differed for all mutants, which ranged from 90.46 to 98.25. Mutant lines $\mathrm{Pb}-\mathrm{M}-1575, \mathrm{~Pb}-\mathrm{M}-12$ waxy, $\mathrm{Pb}-\mathrm{M}-2041$, and $\mathrm{Pb}-\mathrm{M}-1802$ showed the earliest heading times, whereas $\mathrm{Pb}-\mathrm{M}-1027$ waxy, $\mathrm{Pb}-\mathrm{M}-2550$, and $\mathrm{Pb}-\mathrm{M}-59$ waxy exhibited later heading times (Table ??). As early heading is a desirable character, mutant lines depicting lesser numbers of days to reach maturity are useful candidates for breeding early-maturing varieties. The plant heights of the mutant lines differed substantially (76.37 to $91.66 \mathrm{~cm}$ ). The tallest plants belonged to $\mathrm{Pb}-\mathrm{M}-1575, \mathrm{~Pb}-\mathrm{M}-1064$, and $\mathrm{Pb}-\mathrm{M}-2041$ lines, while the shortest plants were recorded for $\mathrm{Pb}-\mathrm{M}-12$ waxy, $\mathrm{Pb}-\mathrm{M}-119$ waxy, and $\mathrm{Pb}-\mathrm{M}-2719$ lines. The mean numbers of spikelets per spike were significantly different among the mutant lines and varied between 17.50 and 20.00. Furthermore, the 1000-grain weights were significantly different among the mutant lines, ranging from 17.60 to $28.42 \mathrm{~g}$. The heaviest grain index values were observed for $\mathrm{Pb}-\mathrm{M}-1027$ waxy, $\mathrm{Pb}-\mathrm{M}-59$ waxy, $\mathrm{Pb}-\mathrm{M}-1854$, and $\mathrm{Pb}-\mathrm{M}-1272$ waxy, while the lightest grain index values were recorded for $\mathrm{Pb}-\mathrm{M}-2728$, $\mathrm{Pb}-\mathrm{M}-12$ waxy, and $\mathrm{Pb}-\mathrm{M}-605$. Correspondingly, substantial variations were observed for grain yields among the mutant lines, ranging from 1648.42 to $3269.98 \mathrm{~kg} / \mathrm{ha}$. These mutant lines exhibited fluctuations in yield, i.e., Pb-M-59 waxy, Pb-M-1272 waxy, Pb-M-2260 produced the maximum grain yield, while $\mathrm{Pb}-\mathrm{M}-12$ waxy, $\mathrm{Pb}-\mathrm{M}-2728$, and $\mathrm{Pb}-\mathrm{M}-1743$ showed the lowest values. We observed significant differences for grain quality traits 
among all mutant lines. Protein contents varied from 12.19 to $13.68 \%$, moisture contents ranged between 8.73 and $9.43 \%$, while gluten contents ranged from 37.67 to 40.96 (Table ??). The mean values for all traits differed from the values for the wild type; however, the maximum fluctuation was found for the relative reductions in grain yield $(34.36 \%$ for $\mathrm{Pb}-\mathrm{M}-59$ waxy and $-29.25 \%$ for Pb-M-12 waxy), followed by TGW. The mean values for the mutants for gluten and moisture contents showed reductions compared to those for the wild type, except for two mutants (Table S1).

Table 5. Mean performance of 32 mutant lines and the wild type for two generations $\left(\mathrm{M}_{7}\right.$ and $\mathrm{M}_{8}$ ) and locations (NIBGE and NIAB).

\begin{tabular}{|c|c|c|c|c|c|c|c|c|c|c|c|}
\hline Sr. \# & Genotypes & DTH & $\begin{array}{c}\text { Plant } \\
\text { Height }\end{array}$ & TPP & $\begin{array}{l}\text { Spike } \\
\text { Length }\end{array}$ & $\begin{array}{l}\text { Number of } \\
\text { Spikelets } \\
\text { Per Spike }\end{array}$ & TGW & $\begin{array}{l}\text { Grain } \\
\text { Yield }\end{array}$ & $\begin{array}{l}\text { Protein } \\
\text { Content }\end{array}$ & $\begin{array}{c}\text { Moisture } \\
\text { Content }\end{array}$ & $\begin{array}{l}\text { Gluten } \\
\text { Content }\end{array}$ \\
\hline 1 & $\begin{array}{l}\mathrm{Pb}-11 \\
\text { parent }\end{array}$ & 96.25 & 88.00 & 5.57 & 12.35 & 18.00 & 22.43 & 2433.71 & 12.22 & 9.35 & 40.25 \\
\hline 2 & $\begin{array}{c}\mathrm{Pb}-\mathrm{M}-1027 \\
\text { waxy }\end{array}$ & 90.46 & 87.91 & 6.33 & 12.48 & 19.00 & 28.04 & 3110.04 & 12.19 & 9.15 & 37.88 \\
\hline 3 & Pb-M-1055 & 95.88 & 88.28 & 5.28 & 12.55 & 18.50 & 22.95 & 2088.02 & 12.85 & 9.11 & 39.67 \\
\hline 4 & Pb-M-1064 & 94.83 & 91.62 & 5.86 & 13.27 & 18.50 & 24.33 & 2442.28 & 13.65 & 9.18 & 40.13 \\
\hline 5 & $\begin{array}{c}\text { Pb-M-119 } \\
\text { waxy }\end{array}$ & 96.61 & 81.20 & 5.38 & 12.25 & 18.50 & 21.00 & 2091.18 & 13.10 & 9.10 & 38.83 \\
\hline 6 & $\begin{array}{c}\text { Pb-M-12 } \\
\text { waxy }\end{array}$ & 98.23 & 76.37 & 4.90 & 11.47 & 18.00 & 18.13 & 1648.42 & 13.29 & 8.78 & 40.96 \\
\hline 7 & $\begin{array}{c}\mathrm{Pb}-\mathrm{M}-1272 \\
\text { waxy }\end{array}$ & 97.46 & 89.61 & 5.86 & 11.72 & 19.00 & 27.08 & 3265.75 & 12.94 & 9.36 & 38.71 \\
\hline 8 & $\begin{array}{c}\mathrm{Pb}-\mathrm{M}-1323 \\
\text { waxy }\end{array}$ & 93.75 & 86.28 & 5.76 & 12.42 & 20.00 & 28.42 & 3082.38 & 12.86 & 8.96 & 39.29 \\
\hline 9 & Pb-M-1530 & 96.75 & 87.15 & 5.67 & 12.91 & 18.50 & 25.19 & 2806.99 & 12.74 & 9.21 & 38.17 \\
\hline 10 & Pb-M-1575 & 98.25 & 91.66 & 5.68 & 13.20 & 18.00 & 22.27 & 2373.52 & 13.45 & 9.23 & 39.11 \\
\hline 11 & Pb-M-1743 & 96.79 & 84.93 & 5.33 & 12.53 & 19.00 & 21.33 & 1917.99 & 12.96 & 8.87 & 39.21 \\
\hline 12 & $\mathrm{~Pb}-\mathrm{M}-1802$ & 97.55 & 87.89 & 5.69 & 12.24 & 18.00 & 24.15 & 2408.46 & 12.73 & 8.94 & 38.92 \\
\hline 13 & Pb-M-1854 & 96.00 & 87.75 & 5.92 & 10.86 & 18.00 & 27.15 & 3001.59 & 13.12 & 9.39 & 39.17 \\
\hline 14 & Pb-M-1917 & 97.42 & 88.55 & 5.10 & 12.73 & 18.00 & 23.91 & 2384.68 & 12.94 & 8.91 & 38.42 \\
\hline 15 & Pb-M-1946 & 96.08 & 88.73 & 5.90 & 12.82 & 20.00 & 23.02 & 2757.61 & 12.76 & 9.12 & 39.38 \\
\hline 16 & Pb-M-2041 & 97.79 & 90.69 & 5.39 & 11.73 & 18.00 & 25.16 & 2911.46 & 12.96 & 9.04 & 38.04 \\
\hline 17 & Pb-M-2061 & 94.75 & 89.87 & 5.60 & 12.16 & 19.00 & 24.50 & 2670.98 & 12.81 & 9.38 & 38.87 \\
\hline 18 & $\mathrm{~Pb}-\mathrm{M}-2260$ & 96.34 & 86.77 & 6.00 & 12.21 & 20.00 & 26.93 & 3219.03 & 12.40 & 9.08 & 37.67 \\
\hline 19 & $\mathrm{~Pb}-\mathrm{M}-2302$ & 97.50 & 86.88 & 5.46 & 11.90 & 18.50 & 23.08 & 2466.15 & 12.95 & 8.93 & 39.88 \\
\hline 20 & $\mathrm{~Pb}-\mathrm{M}-2443$ & 95.75 & 87.14 & 5.50 & 12.45 & 19.00 & 21.63 & 2417.59 & 13.08 & 8.99 & 39.75 \\
\hline 21 & $\mathrm{~Pb}-\mathrm{M}-2453$ & 95.08 & 89.47 & 6.32 & 13.50 & 20.00 & 23.55 & 2192.27 & 13.23 & 9.16 & 39.96 \\
\hline 22 & Pb-M-2517 & 95.25 & 86.44 & 5.29 & 13.31 & 18.50 & 23.17 & 2572.64 & 12.90 & 9.00 & 40.19 \\
\hline 23 & $\mathrm{~Pb}-\mathrm{M}-2550$ & 92.92 & 88.75 & 5.29 & 12.39 & 18.50 & 21.43 & 2175.05 & 13.68 & 9.19 & 39.08 \\
\hline 24 & Pb-M-2637 & 94.49 & 84.21 & 5.18 & 12.83 & 18.50 & 21.26 & 2145.48 & 12.38 & 9.02 & 39.45 \\
\hline 25 & Pb-M-2719 & 94.17 & 83.85 & 5.34 & 11.66 & 18.50 & 22.48 & 2240.87 & 13.28 & 8.84 & 40.00 \\
\hline 26 & $\mathrm{~Pb}-\mathrm{M}-2725$ & 96.50 & 87.18 & 5.71 & 13.04 & 19.00 & 21.91 & 2261.81 & 13.21 & 8.95 & 39.55 \\
\hline 27 & $\mathrm{~Pb}-\mathrm{M}-2728$ & 96.67 & 86.46 & 5.90 & 12.49 & 18.50 & 17.60 & 1721.88 & 13.50 & 9.43 & 39.25 \\
\hline 28 & $\mathrm{~Pb}-\mathrm{M}-2768$ & 94.42 & 87.55 & 5.63 & 12.80 & 18.50 & 24.94 & 2801.25 & 13.16 & 8.79 & 38.42 \\
\hline
\end{tabular}


Table 5. Cont.

\begin{tabular}{cccccccccccc}
\hline Sr. \# & Genotypes & DTH & $\begin{array}{c}\text { Plant } \\
\text { Height }\end{array}$ & TPP & $\begin{array}{c}\text { Spike } \\
\text { Length }\end{array}$ & $\begin{array}{c}\text { Number of } \\
\text { Spikelets } \\
\text { Per Spike }\end{array}$ & TGW & $\begin{array}{c}\text { Grain } \\
\text { Yield }\end{array}$ & $\begin{array}{c}\text { Protein } \\
\text { Content }\end{array}$ & $\begin{array}{c}\text { Moisture } \\
\text { Content }\end{array}$ & $\begin{array}{c}\text { Gluten } \\
\text { Content }\end{array}$ \\
\hline 29 & Pb-M-2778 & 95.33 & 88.72 & 5.71 & 13.29 & 19.00 & 22.61 & 2600.04 & 12.82 & 8.98 & 39.92 \\
\hline 30 & $\begin{array}{c}\text { Pb-M-334 } \\
\text { waxy }\end{array}$ & 95.58 & 86.78 & 5.44 & 12.08 & 18.50 & 21.97 & 2118.48 & 13.55 & 8.90 & 40.04 \\
\hline 31 & Pb-M-583 & 94.71 & 87.06 & 5.49 & 13.37 & 18.00 & 22.83 & 2342.93 & 13.42 & 9.13 & 39.50 \\
\hline 32 & $\begin{array}{c}\text { Pb-M-59 } \\
\text { waxy }\end{array}$ & 92.97 & 84.38 & 5.24 & 12.00 & 17.50 & 27.42 & 3269.98 & 12.84 & 8.81 & 38.58 \\
\hline 33 & $\mathrm{~Pb}-\mathrm{M}-605$ & 95.17 & 86.71 & 5.35 & 13.05 & 19.50 & 20.55 & 1970.30 & 13.65 & 9.05 & 40.97 \\
\hline
\end{tabular}

DTH: number of days to heading; TPP: number of tillers per plant; TGW: 1000-grain weight.

\subsection{Cluster Analysis Based upon Yield Index}

The yield index values for 32 mutant lines and the wild type were computed to classify the evaluated mutant lines according to their yield potential. The mutant lines were clustered into three groups using hierarchical clustering. Group " $\mathrm{A}$ " comprised two mutant lines with the lowest grain yields, while group " $\mathrm{B}$ " contained 18 mutant lines with high grain yield values; however, group " $C$ " consisted of 13 mutant lines that had the highest grain yield values (Figure ??). Different colors represent different clusters in Figure ??.

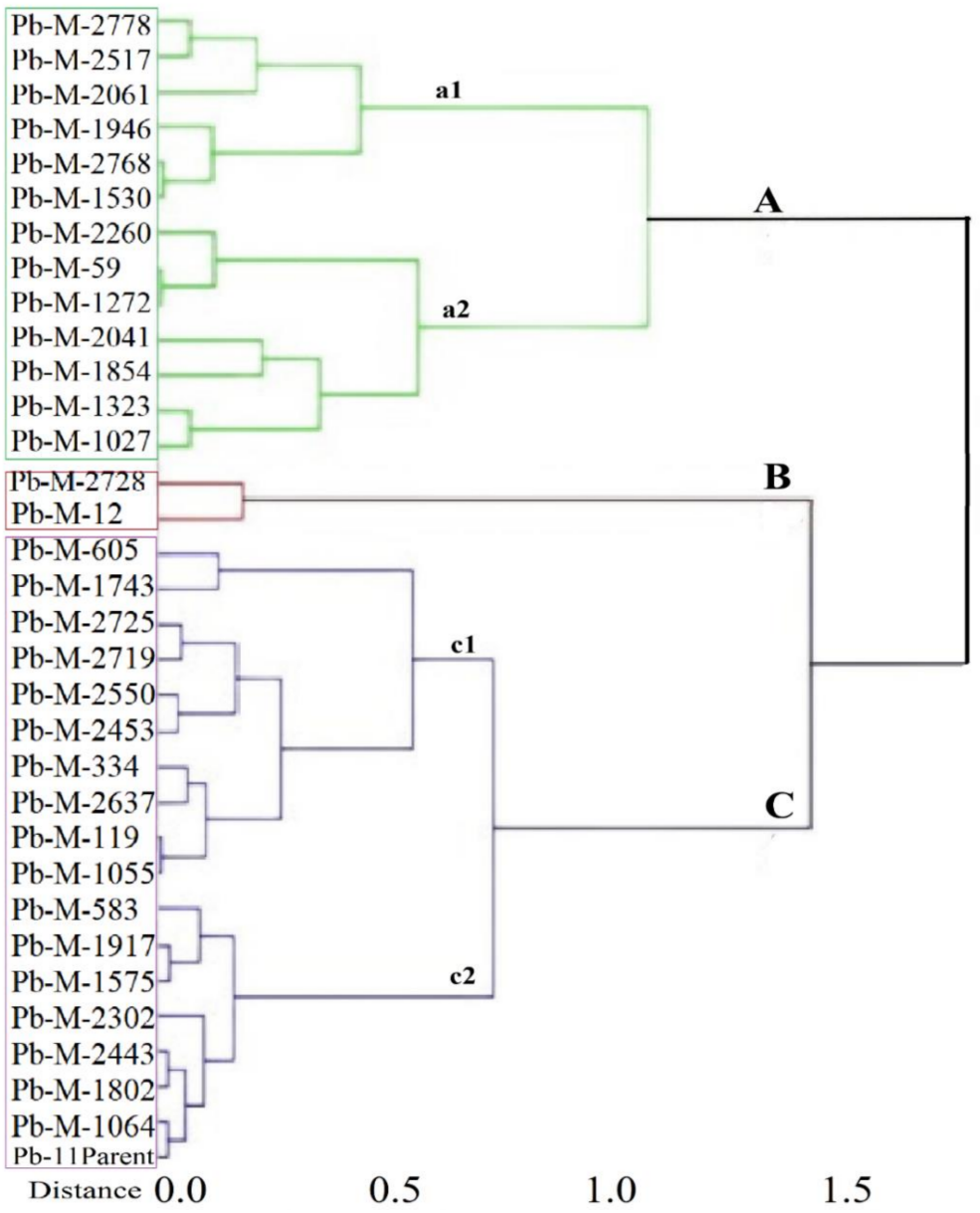

Figure 5. Cluster dendrogram of 32 mutant lines and the wild type based upon mean yield index values calculated for both generations $\left(\mathrm{M}_{7}\right.$ and $\left.\mathrm{M}_{8}\right)$ and locations (NIBGE and NIAB). 


\subsection{Principal Component Analysis (PCA)}

In the present study, PCA was used to categorize the traits into six main principal components (PCs). For all morphological and quality traits, $90.28 \%$ variation was contributed by the first six components showing Eigen values greater than 0.5 . The first PC accounted for $35.99 \%$, the second PC for $18.36 \%$, the third PC for $12.50 \%$, and the fourth PC for approximately $8.84 \%$ of the total variation (Table ??). Furthermore, the rotation component matrix revealed that each PC contained different combinations of morphological and quality traits. The first PC showed linkages between grain quality (protein, moisture, and gluten contents) and yield components, including plant height, tillers per plant, 1000-grain weight, and grain yield; thus, PC1 allowed the simultaneous selection of morphological and quality traits. Similarly, the second PC exhibited positive effects in terms of the spike length, number of spikelets per spike, number of tillers per plant, and plant height. The third PC explained the moisture content, number of days to produce heads, and number of spikelets per spike (Table ??).

Table 6. Principal component analysis showing Eigen values, percentages of variance, and cumulative percentages for all traits.

\begin{tabular}{ccccc}
\hline Traits & $\begin{array}{c}\text { Principal Component } \\
(\text { PC) }\end{array}$ & Eigen Value & $\begin{array}{c}\text { Percent } \\
\text { Variance }\end{array}$ & $\begin{array}{c}\text { Cumulative } \\
\text { Percentage }\end{array}$ \\
\hline Days to heading & PC1 & 3.5986 & 35.99 & 35.99 \\
\hline Plant height & PC2 & 1.8355 & 18.36 & 54.34 \\
\hline Tillers per plant & PC3 & 1.2496 & 12.5 & 66.84 \\
\hline Spike length & PC4 & 0.8840 & 8.84 & 75.68 \\
\hline $\begin{array}{c}\text { Number of spikelets } \\
\text { per spike }\end{array}$ & PC5 & 0.8125 & 8.13 & 83.8 \\
\hline $\begin{array}{c}\text { 1000-grain weight } \\
\text { Grain Yield }\end{array}$ & PC6 & 0.6463 & 6.46 & 90.27 \\
\hline Protein content & PC7 & 0.4393 & 4.39 & 94.66 \\
\hline Moisture content & PC8 & 0.2842 & 2.84 & 97.5 \\
\hline Gluten content & PC9 & 0.1825 & 1.83 & 99.33 \\
\hline
\end{tabular}

Table 7. Rotation component matrix of different traits with Eigen values $>0.5$ in the first five components.

\begin{tabular}{ccccc}
\hline PC1 & PC2 & PC3 & PC4 & PC5 \\
\hline Grain yield & Spike length & Moisture content & $\begin{array}{c}\text { Number of } \\
\text { spikelets per spike }\end{array}$ & $\begin{array}{c}\text { Days to } \\
\text { heading }\end{array}$ \\
\hline $\begin{array}{c}\text { 1000-grain } \\
\text { weight }\end{array}$ & $\begin{array}{c}\text { Number of } \\
\text { spikelets per } \\
\text { spike }\end{array}$ & Days to heading & - & - \\
\hline Tillers per plant & Plant height & $\begin{array}{c}\text { Number of } \\
\text { spikelets per } \\
\text { spike }\end{array}$ & - & - \\
\hline Gluten content & Tillers per plant & - & - & - \\
\hline Plant height & - & - & - & - \\
\hline Protein content & - & - & - & - \\
\hline Moisture content & - & & - & - \\
\hline
\end{tabular}




\subsection{Genotype by Trait (GT) Bi-Plot Analysis}

3.6.1. Interrelation among Different Traits

The GT data presented in Tables S2 and S3 show trait means for each of the 32 mutant lines plus the wild type screened across two locations for the period 2018-2020. The GT bi-plot based on trait-standardized data shows that the cosine of the angles between morphological trait vectors estimates the degree of correlation between them; hence, the angles $<90^{\circ}$ (acute angles) show positive association, the angles $>90^{\circ}$ depict the negative correlations, and exact angles of $90^{\circ}$ indicate the absence of correlation between traits [? ].

The GT bi-plot of the mean performance of all the mutant lines explained $49.1 \%$ of the total variation for the NIAB location (Figure ??). Based on the relationships between traits, different groups for the traits under study were identified, with different responses in terms of discriminating the mutant lines. Across the 32 mutant lines plus the wild type, plant height, 1000-grain weight, and grain yield values were positively associated (acute angles); however, these traits were negatively correlated with grain quality parameters such as protein, moisture, and gluten contents (obtuse angles); and were independent of the numbers of tillers per plant (near right angles). These relationships suggest that it is possible to combine higher yield, plant height, 1000-grain weight, and tillers per plant in a single mutant line (Figure ??).

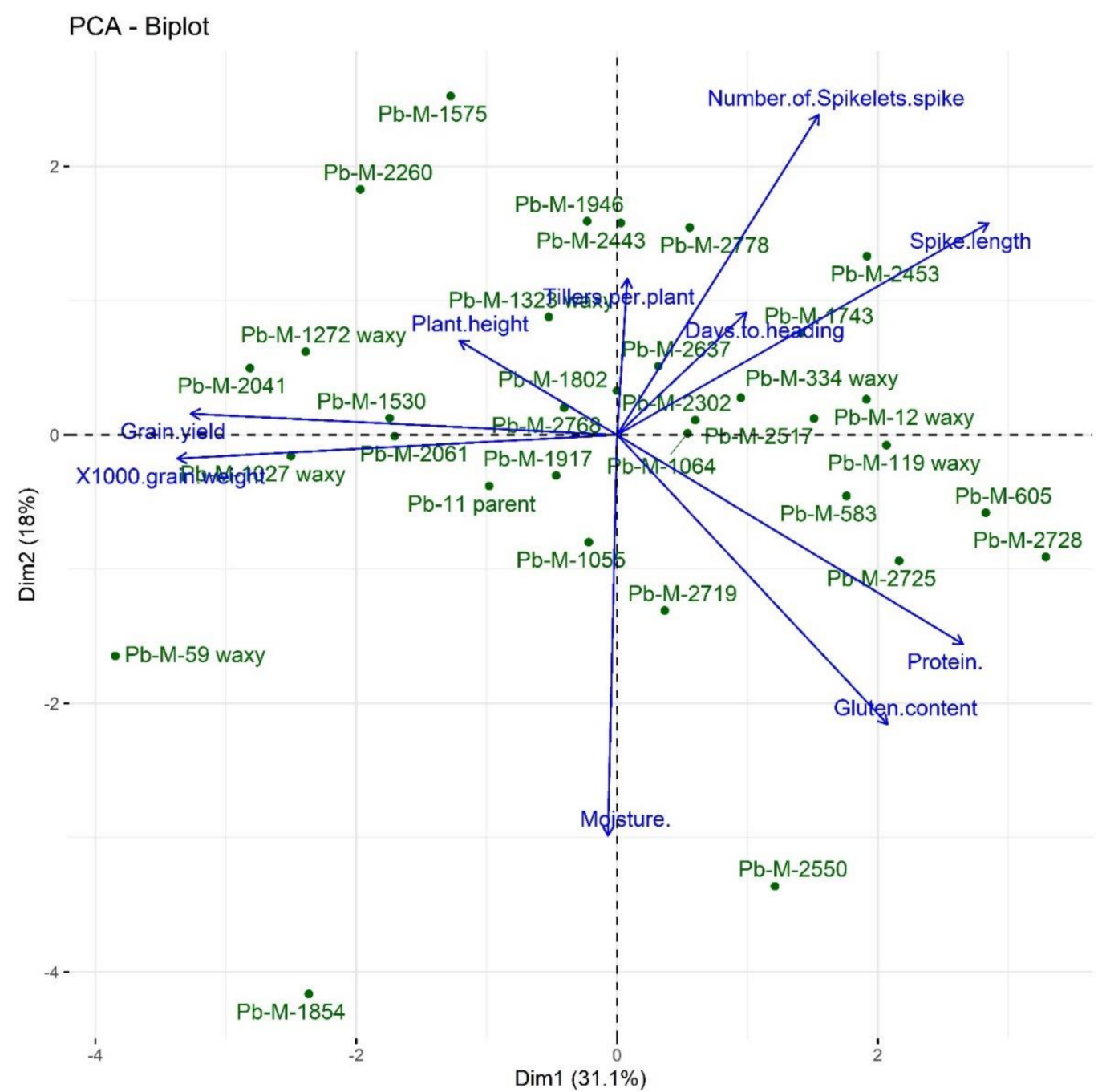

Figure 6. Genotype by trait bi-plot showing the associations among morphological and quality traits of 32 mutant lines and the wild type in $\mathrm{M}_{7}$ and $\mathrm{M}_{8}$ generations at the NIAB location. 
The mutant line $\mathrm{Pb}-\mathrm{M}-59$ waxy produced the maximum grain yield and kernel weight; however, it exhibited a lower gluten content and protein percentage. As such, it is an ideal mutant line for incorporating high yield potential and protein contents. It is also indicated in Figure ?? that Pb-M-1854 combined all favorable traits, as it had a high grain yield and 1000-grain weight, as well as good protein content, moisture, and gluten content levels. Other mutant lines such as Pb-M-2778, Pb-M-2453, Pb-M-1743, Pb-M-334 waxy, $\mathrm{Pb}-\mathrm{M}-2637$, and $\mathrm{Pb}-\mathrm{M}-2302$ were located opposite to the origin of $\mathrm{Pb}-\mathrm{M}-59$ waxy and $\mathrm{Pb}-\mathrm{M}-$ 1854 relative to the bi-plot origin because their trait profiles were opposite. They had the highest numbers of spikelets per spike, spike lengths, days to heading, and intermediate numbers of tillers per plant. These mutant lines might be good candidates for studying the genetic determination of spike length and number of spikelets per spike in bread wheat. For grain quality parameters, $\mathrm{Pb}-\mathrm{M}-2725, \mathrm{~Pb}-\mathrm{M}-2550, \mathrm{~Pb}-\mathrm{M}-2728$, and $\mathrm{Pb}-\mathrm{M}-2719$ might be good mutant lines for studying the genetic basis of gluten, moisture, and protein content in mutant wheat population. In addition, many other relationships can be inferred (Figure ??), for example Pb-M-1272 waxy, Pb-M-2041, Pb-M-2260, Pb-M-1575, Pb-M-1530, and $\mathrm{Pb}-\mathrm{M}-1323$ waxy constituted a group of mutant lines sharing the same trait profiles, while $\mathrm{Pb}-\mathrm{M}-2061, \mathrm{~Pb}-\mathrm{M}-1027$ waxy, and $\mathrm{Pb}-\mathrm{M}-1917$ formed another group. It would be logical to guess that the mutant lines within each group might harbor the same or similar alleles for the respective traits. Finally, it can be concluded that higher yield is negatively correlated with grain quality parameters.

For location NIBGE, the GT bi-plot of the mean performance of all the mutant lines explained $50.8 \%$ of the total variation. Across the 32 mutant lines and the wild type, 1000-grain weight, plant height, and grain yield values were positively associated, as an acute angle was present between these traits. These three traits were negatively correlated with other traits such as protein content, gluten content, and days to heading (obtuse angles), and they were independent of the number of spikelets per spike (near right angles) (Figure ??). Total grain yield was also positively correlated with plant height, number of tillers per plant, and the number of spikelets per spike. Additionally, number of spikelets per spike, plant height, number of tillers per plant, and moisture content were positively correlated; however, spike length was negatively correlated with gluten content, protein content, and number of days to heading (an obtuse angle) (Figure ??). These relationships suggest that it is possible to combine higher yield, plant height, 1000-kernal weight, and tillers per plant in a single wheat mutant line.

The mutant lines $\mathrm{Pb}-\mathrm{M}-1323$ waxy and $\mathrm{Pb}-\mathrm{M}-1027$ waxy exhibited the highest grain yields and 1000-grain weights, lower gluten and protein contents, and required lower numbers of days to reach maturity. Additionally, it is also evident that Pb-M-2453 accumulated all favorable traits, as it had a high yield and 1000-grain weight, as well as good protein, moisture, and gluten content levels (Figure ??). Other mutant lines such as Pb-M-2260, Pb-M-2453, Pb-M-2061, Pb-M-1946, Pb-M-1854, and Pb-M-1272 waxy showed the highest plant heights, numbers of tillers per plant, numbers of spikelets per spike, and moisture content levels. These observations suggest that mutant lines are useful for the genetic determination of yield-dependent attributes in wheat mutant populations. For grain quality parameters, mutant lines $\mathrm{Pb}-\mathrm{M}-1575$ and $\mathrm{Pb}-\mathrm{M}-2728$ could be explored to study the genetic basis of grain quality traits in bread wheat. All of the mutant lines showed varying degrees of association with multiple traits separately. For instance, Pb-M-2041, $\mathrm{Pb}-\mathrm{M}-1575, \mathrm{~Pb}-\mathrm{M}-334$ waxy, $\mathrm{Pb}-\mathrm{M}-2302$, and $\mathrm{Pb}-\mathrm{M}-2728$ constituted a group of mutant lines with similar trait profiles, while $\mathrm{Pb}-\mathrm{M}-1027$ waxy, $\mathrm{Pb}-\mathrm{M}-1323$ waxy, and $\mathrm{Pb}-\mathrm{M}-2768$ constituted a different group of mutant lines sharing the same trait profiles (Figure ??). As demonstrated in the NIAB site experiment, grain yield and quality (protein and gluten contents) were also found to be negatively correlated at the NIBGE site, confirming the existence of a negative correlation between both traits. 


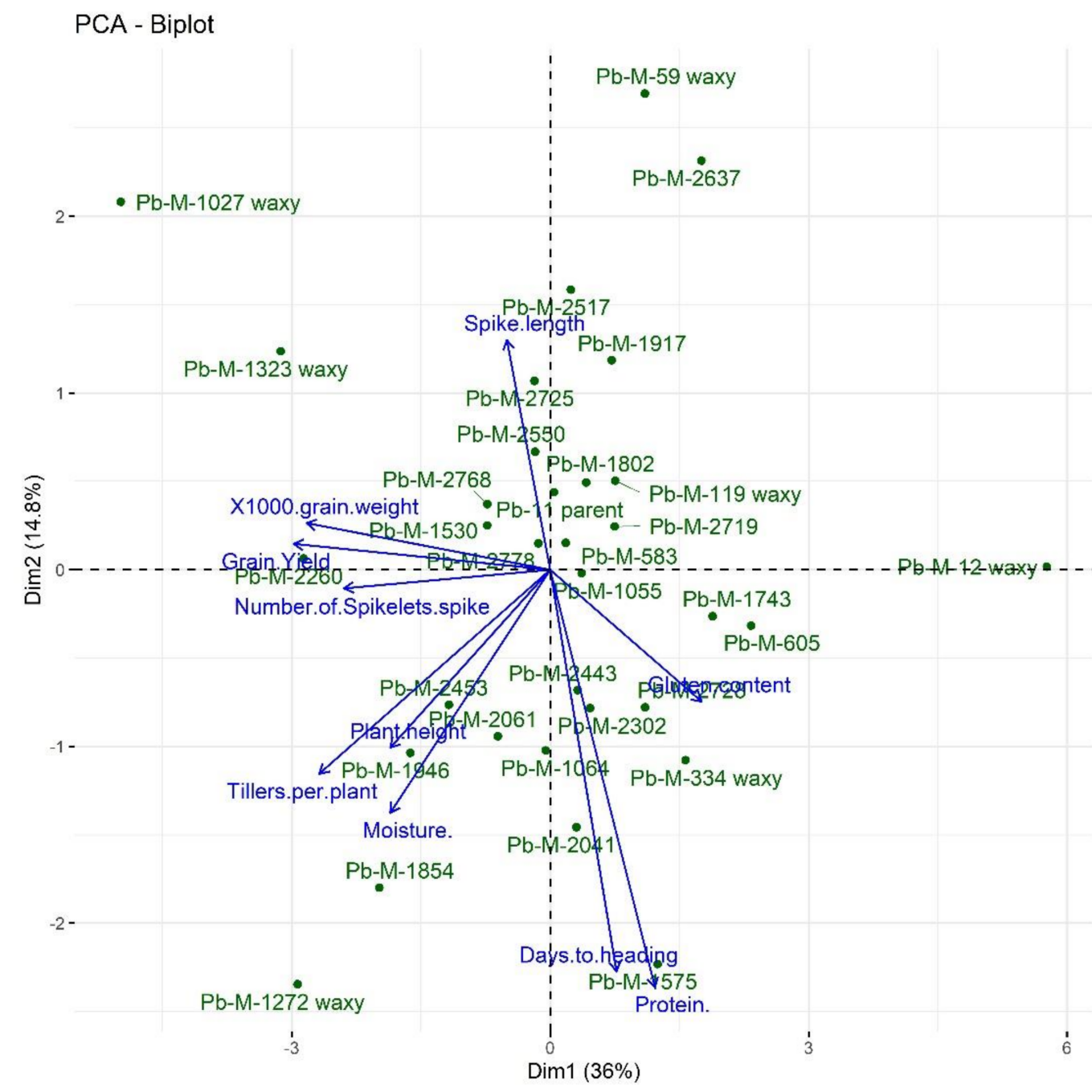

Figure 7. Genotype by trait bi-plot showing the associations among morphological and quality traits of 32 mutant lines and the wild type in $\mathrm{M}_{7}$ and $\mathrm{M}_{8}$ generations at the NIBGE location.

\subsubsection{Genotype by Trait Profiles}

The polygon view of the bi-plot helps in the identification and selection of mutant lines having the highest values for one or multiple traits. The mutant lines present at the vertex can be characterized for particular traits, while genotypes close to the bi-plot origin can be evaluated for a wide range of traits. Based on the trait associations, different groups of traits with different responses formed the basis of the mutant line discrimination. The vertex mutant lines in this investigation were $\mathrm{Pb}-\mathrm{M}-59$ waxy, $\mathrm{Pb}-\mathrm{M}-1854, \mathrm{~Pb}-\mathrm{M}-2550$, $\mathrm{Pb}-\mathrm{M}-2728, \mathrm{~Pb}-\mathrm{M}-2453$, and $\mathrm{Pb}-\mathrm{M}-1575$ (Figure ??). The vertex mutant lines were the most genetically diverse for some or all traits owing to having the longest distance from the origin of the bi-plot. Total grain yield and 1000-grain weight values fell in the Pb-M-59 waxy sector (Figure ??), suggesting that $\mathrm{Pb}-\mathrm{M}-59$ waxy had the highest or nearly the highest values for these traits. Similarly, other mutant lines such as $\mathrm{Pb}-\mathrm{M}-1854$ had high values for moisture content, $\mathrm{Pb}-\mathrm{M}-2550$ had a high gluten content, and $\mathrm{Pb}-\mathrm{M}-2725$ showed a high protein content. The bi-plot analysis did not explain all of the variation; thus, these predictions may vary for the observed numbers [? ]. As illustrated in Figure ??, Pb-M-59 waxy had a vector length higher than the remaining mutant lines, showing the maximum values in terms of grain yield, 1000-grain weight, and good protein content; therefore, it is a suitable mutant line for improving the yield and quality of wheat. In addition, mutant lines having higher vector lengths, such as $\mathrm{Pb}-\mathrm{M}-2041, \mathrm{~Pb}-\mathrm{M}-1272$ waxy, and $\mathrm{Pb}-\mathrm{M}-1027$ waxy, also presented high values for grain yield and 1000-grain weight. Likewise, the maximum 
numbers of spikelets per spike and spike lengths were recorded for $\mathrm{Pb}-\mathrm{M}-2778, \mathrm{~Pb}-\mathrm{M}-1743$, and $\mathrm{Pb}-\mathrm{M}-2453$.

\section{Which Won Where/What}

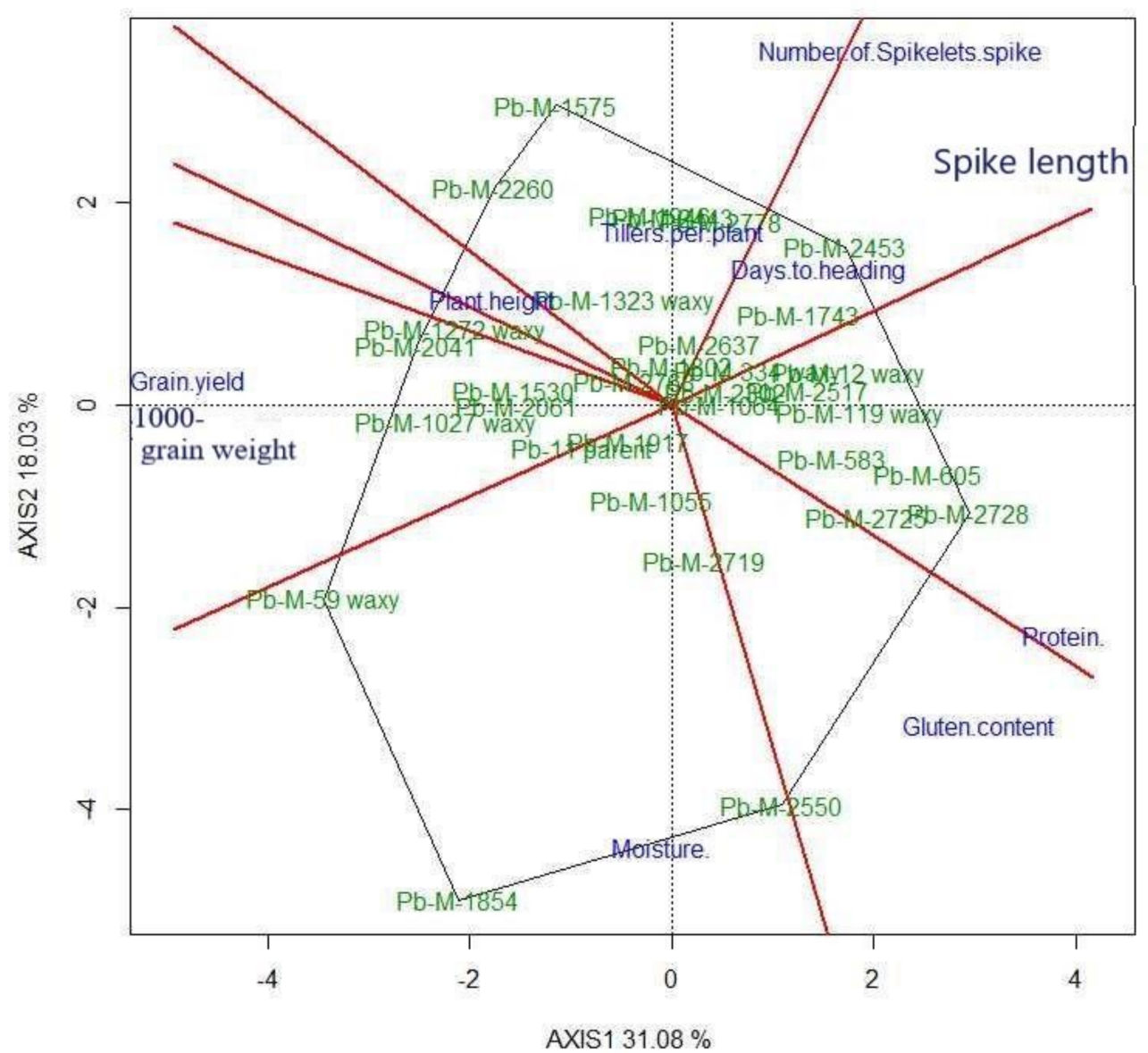

Figure 8. Polygon view of the GT bi-plot of 32 mutant lines and the wild type sown at the NIAB location.

Regarding the polygon plot of the NIBGE location, the vertex mutant lines were $\mathrm{Pb}-\mathrm{M}-59$ waxy, Pb-M-12 waxy, Pb-M-1027 waxy, Pb-M-1575, and Pb-M-1272 waxy (Figure ??). The grain yield and 1000-grain weight traits fell in the Pb-M-1027 waxy sector, suggesting that $\mathrm{Pb}-\mathrm{M}-1027$ waxy had the highest or nearly the highest values for these traits. Likewise, $\mathrm{Pb}-\mathrm{M}-1272$ waxy showed the highest values in terms of plant height, tillers per plant, and moisture content. Pb-M-1575 showed high values in terms of protein content and days to heading, while $\mathrm{Pb}-\mathrm{M}-12$ waxy showed high gluten content. As illustrated in Figure ??, Pb-M-1027 waxy had the longest vector length, followed by Pb-M-12 waxy and $\mathrm{Pb}-\mathrm{M}-59$ waxy. Likewise, the highest values in terms of plant height, moisture content $\%$, and tillers per plant were obtained for $\mathrm{Pb}-\mathrm{M}-1272$ waxy, $\mathrm{Pb}-\mathrm{M}-1946$, and $\mathrm{Pb}-\mathrm{M}-1854$ (Figure ??). 
Which Won Where/What

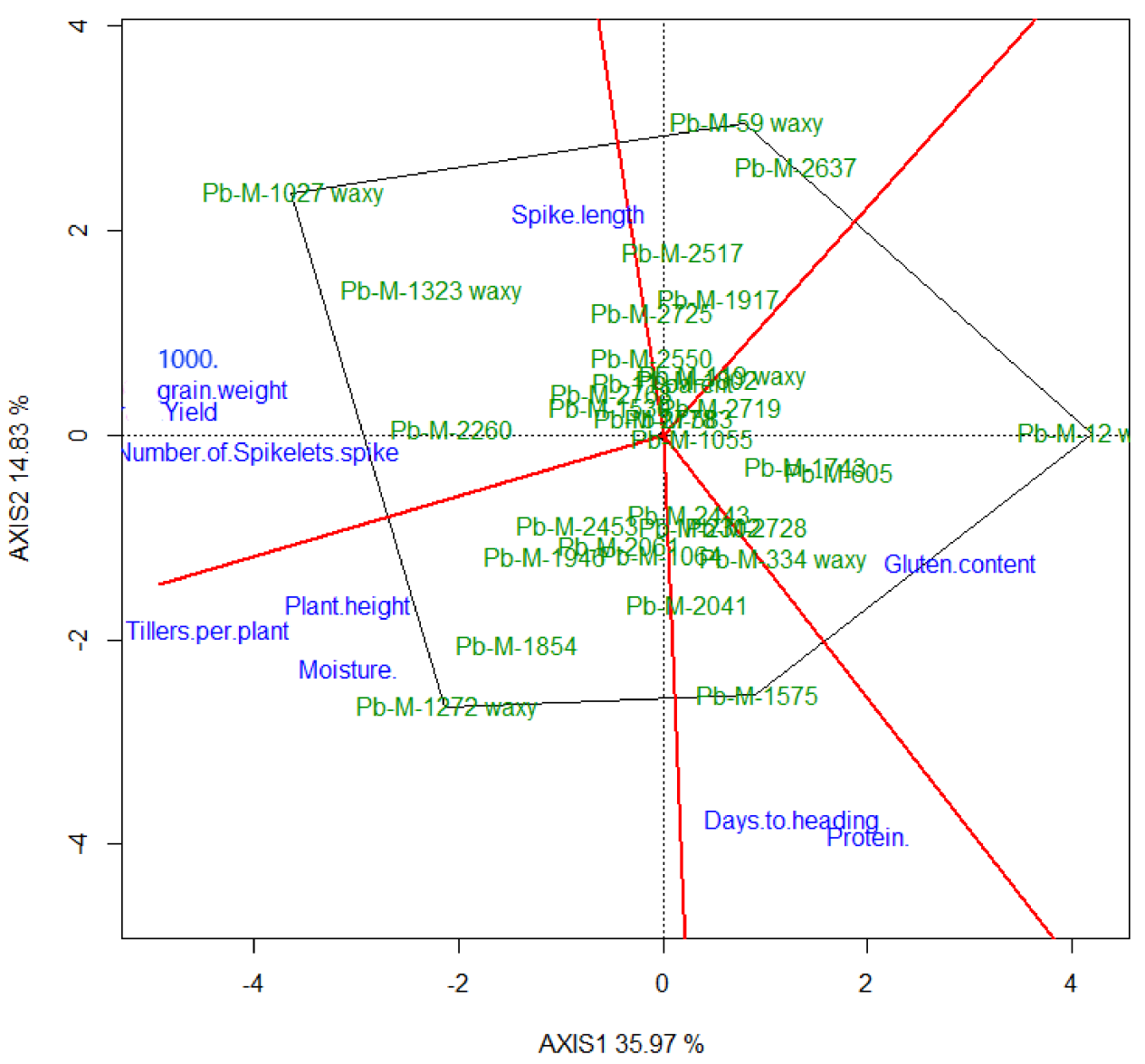

Figure 9. Polygon view of the GT bi-plot of 32 mutant lines and the wild type at the NIBGE location.

\section{Discussion}

The characterization and screening of bread wheat cultivars based on variations in agro-morphological traits are fundamental objectives in wheat breeding programs for the development of high-yielding wheat varieties [? ]. The current study evaluated the potential of gamma-irradiated wheat mutant lines in terms of inducing morpho-quality traits, as well as their associations with yield.

\subsection{Morphological Traits}

Studying the variations in various morphological traits is important for characterizing diverse wheat genetic recourses, and these variations can be exploited in wheat breeding programs. Analysis of variance and other related genetical tools can help in designing suitable breeding criteria, which together can make a crop improvement program effective [? ]. The evaluated mutant lines expressed substantial variations in plant height, spike length, and 1000-kernel weight for two consecutive years (????, ????). The variations in morphological traits showed that the newly developed mutant lines can be used to develop genetically diverse and improved wheat varieties. For instance, a wide range of variations in yield-related traits was recorded. Such commonalities in terms of inducing mutations in complex traits controlling yield through physical mutagens have been reported [? ? ? ? ? ], which are consistent with our observations. Similarly, highly significant levels of divergence for different morpho-quality traits among wheat cultivars were also reported in earlier studies [? ? ? ? ? ], suggesting that the evaluation of mutant lines based on morpho-quality traits is a suitable criterion, as proven in the present study. 


\subsection{Multivariate Analysis}

In the present study, 32 mutant lines and a wild type were grouped into three clusters based on the yield index (Figure ??). No duplicates were identified for grain yield among the mutant lines, elucidating the occurrence of genetic diversity in terms of grain yield. In accordance with the current findings, diversity among wheat genotypes was estimated using cluster analysis [? ? ? ? ]. The grain yield is a very complicated trait, and continuous efforts are ongoing around the world in terms of identifying various mechanisms conferring different yield components. The present study provides a basis for breeders and geneticists seeking to add these mutants to their genetic resource bin, which will complement future studies aiming to unravel the secrets of the corresponding traits.

The present study also highlighted the degrees of association and dependence among grain yield, yield component, and quality parameters for the mutant lines. In the PCA, six major components were extracted for all traits; however, the first three components with Eigen values $>1$ accounted for $66.84 \%$ of the total variability. Morphological traits, e.g., plant height, days to heading, tillers per plant, number of spikelets per spike, and grain yield, exhibited the maximum loading values contributing positively towards the entire variation. Our findings are in accordance with some earlier studies demonstrating that certain agronomic traits such as days to heading and maturity, plant height, and 1000-grain weight were strong correlated with grain yield [? ]. It is suggested that the extent of genetic variation induced through mutations follows the same pattern of associations among the traits, as was reported for the recombinant breeding wheat populations. In the current study, the first two PCs covered multiple traits, including grain yield, 1000-grain weight, and quality traits, which contributed $54.34 \%$ of the total variation. Similar findings were also reported by Meena et al. [? ], whereby the grain yield potential of recombinant inbred lines was evaluated using PCA, showing that $63.6 \%$ of the variation was contributed by the first two components containing grain yield, 1000-kernel weight, and quality traits. Furthermore, similar results were reported for wheat in earlier studies [? ? ], indicating the reliability of our findings. Our study revealed that for the genetic improvement of grain yield, breeders could select the mutant lines expressing superior performance for 1000-grain weight, tillers per plant, number of spikelets per spike, and plant height. Among these, grain yield and yield components are the most important traits, which may lead to achieving higher grain yields.

In conclusion, indirect selection using plant height, number of tillers per plant, spike length, number of spikelets per spike, and 1000-kernel weight parameters can be exercised for the genetic improvement of wheat grain yield. Along with yield components, some important quality traits such as protein and moisture contents could be targeted to improve wheat quality.

\subsection{GT Bi-Plot Analysis}

A complete understanding of the associations among multiple traits and genotypes helps in designing breeding goals that pave the way for exercising indirect selection of other traits [? ]. In the current study, the bi-plot grouped the traits under study, which exhibited varying degrees of correlation with each other. Positive correlations were found among 1000-kernel weight, plant height, number of spikelets per spike, number of tillers per plant, and grain yield, as indicated by the acute angles between their respective vectors $\left(<90^{\circ}\right)$. Additionally, different mutant lines depicted associations with different groups of traits; thus, the bi-plot exhibited excellent discrimination ability in selecting a specific genotype with a particular trait and in recommending a genotype for a particular trait. By adopting this technique, we are able to propose that mutant lines $\mathrm{Pb}-\mathrm{M}-59$ waxy and $\mathrm{Pb}-\mathrm{M}-1027$ waxy are suitable candidates for improving wheat yield, while $\mathrm{Pb}-\mathrm{M}-2728$ and $\mathrm{Pb}-\mathrm{M}-2550$ are suitable for enhancing grain quality. A similar approach was described in previous studies, showing that an assessment of visual comparisons can be made by producing a GT-bi plot, meaning the best-performing genotypes can be identified [? ? ? ? ]. 
In the current investigation, the GT bi-plot explained $49.1 \%$ and $50.8 \%$ of the total variation for the NIAB and NIBGE locations, respectively. Strong associations among plant height, grain weight, and grain yield were found during both seasons at both locations. It was also shown that yield is positively correlated with yield components but negatively correlated with grain quality traits. The negative associations between grain yield and quality (protein and gluten contents) at both study locations should be considered in the selection of parents or mutants of either trait. Such associations were also reported in earlier studies [? ? ].

Selection for high-yielding wheat mutant lines can be undertaken by exercising indirect selection for yield components, as found in the bi-plot analysis. The mutant lines showing long vector lengths are high yielding. For example, mutant line Pb-M-59 waxy and $\mathrm{Pb}-\mathrm{M}-1854$ depicted higher vector lengths than the other mutant lines. These mutants showed the highest values for grain yield, 1000-grain weight, and above-medium protein content; therefore, these mutant lines are suitable candidates for improving wheat yield and quality, as well as for conducting molecular genetic experiments. These propositions are based on the fact that the vector length has been found to be the most reliable criterion for selecting a high-yielding genotype [? ]. These genotypes can be released as commercial varieties or can at least be utilized in wheat breeding programs.

The "which-won-where" polygon graph serves as a useful tool for assessing the trait profiles of individual genotypes [? ]. The polygon plot also helps in identification and selection of genotypes having superior performance for particular traits that can be used in wheat improvement programs [? ]. In the current study, an irregular polygon was formed by interconnecting all of the mutant lines with the longest vector lengths in all possible directions. Each side of the polygon comprised different sectors with different yield-trait combinations; each sector comprised a vertex mutant line. As such, mutant lines occurred at $\mathrm{Pb}-\mathrm{M}-59$ waxy, $\mathrm{Pb}-\mathrm{M}-1027$ waxy, and $\mathrm{Pb}-\mathrm{M}-1854$ vertices, among others, which showed better performance for yield-trait combinations as compared to the other mutant lines. The GT Bi-plot analysis used to differentiate genotypes based on multiple traits and to find kinship among the traits has been used in many crops, such as safflower [? ], mung bean [? ], barley [? ], cotton [? ], dry beans [? ], durum wheat [? ], maize [? ], and rice [? ].

In summary, it can be stated that the GT bi-plot analysis has been proven to be an effective tool for visualizing genotype and trait data for mutant wheat lines. It also provided the basis for visual comparisons and revealed interrelations among multiple traits and genotypes. Overall, these observations suggest its greater utility in wheat improvement programs and molecular genetics studies.

\section{Conclusions}

Achieving maximum grain yield is required to meet the increasing global food demands. Here, highly productive mutants were identified, which can be used for breeding and or direct cultivation. The analysis of data for multiple traits using the genotype by trait (GT) bi-plot methodology revealed that the GT bi-plot facilitated visual comparisons and the selection of wheat mutant lines. The GT bi-plot analysis of 32 mutant lines and a wild type showed a wide range of associations among traits and indicated that the most important traits for improving wheat varieties are grain yield, 1000-grain weight, number of tillers per plant, number of spikelets per spike, and plant height. It was also evident from the present findings that considerable variation was present among the mutant lines. It is also suggested that it is possible to develop mutant lines with contrasting traits that can be used to enhance genetic wheat resources. Mutant lines $\mathrm{Pb}-\mathrm{M}-59$ waxy, Pb-M-1027 waxy, $\mathrm{Pb}-\mathrm{M}-1854$, $\mathrm{Pb}-\mathrm{M}-2728$, and $\mathrm{Pb}-\mathrm{M}-2550$ can be targeted as potential candidates to improve wheat yield and grain quality. The methodology described in the present study is a useful assay for selecting high-yielding wheat genotypes with high grain quality. These mutants can be used in wheat improvement programs, as well as in exploring the genetic mechanisms of useful traits in wheat and other crops. 
Supplementary Materials: The following are available online at https: / www.mdpi.com/article/ 10.3390/agronomy11090000/s1: Table S1: Trait means for each of the 32 mutant lines plus the wild type screened at NIAB over the period 2018-2020. Table S2: Trait means for each of the 32 mutant lines plus the wild type screened at NIAB over the period 2018-2020. Table S3: Trait means for each of the 32 mutant lines plus the wild type screened at NIBGE over the period 2018-2020.

Author Contributions: Conceptualization, M.-u.-R.; methodology, M.-u.-R.; formal analysis, S.Z., and M.I.; data curation, S.Z., and S.I.; writing-original draft preparation, S.Z., and M.-u.-R.; writingreview and editing, S.Z.; M.-u.-R., and M.A.N.; visualization, S.Z., M.-u.-R., and M.A.N.; funding acquisition, M.-u.-R. All authors have read and agreed to the published version of the manuscript.

Funding: This research work was funded by the International Atomic Energy Commission (IAEA), Vienna, Austria, through a project entitled "Developing Germplasms through TILLING in Crop Plants Using Mutation and Genomic Approaches (PAK/5/047)". We also acknowledge the support of the Higher Education Commission (HEC), Islamabad, Pakistan, for continuing the activities of the IAEA project towards the logical end through a project entitled "Identification of Disease and Insect Mutants using SSR and Next-Generation Sequencing Tools (6103-NRPU/R\&D/HEC-2016)". Funds for publication were utilized from the project entitled "Characterization of mutants derived from EMS-derived Gandum-1 for rust and drought tolerance for sustaining wheat yield in Pakistan", funded by Agriculture Linkage Program, Pakistan Agriculture Research Council (ALP-PARC, CS049).

Data Availability Statement: The data from the manuscript can be found within the article, as well as in the Supplementary Files.

Acknowledgments: We thank the International Atomic Energy Commission (IAEA), Vienna, Austria, for providing funds through an umbrella project entitled “Developing Germplasms through TILLING in Crop Plants Using Mutation and Genomic Approaches (PAK/5/047) for inducing mutations in wheat. We are also grateful to the HEC, Islamabad, Pakistan, for providing financial support used to continue the activities of previous projects through a project entitled "Identification of Disease and Insect Mutants using SSR and Next-Generation Sequencing Tools (6103-NRPU/R\&D/HEC-2016).

Conflicts of Interest: The authors had no conflict of interest. Additionally, the funding agency did not play any role in planning of the experiments, data collection, explaining the results, or writing of the manuscript. The funders also had no role in making decisions regarding publishing the results.

\section{References}

1. Foreign Agricultural Service/USDA. World agricultural production, Circular series, WAP 8-21, August 2021. 2021. Available online: https:/ / apps.fas.usda.gov/psdonline/circulars/production (accessed on 27 August 2021).

2. Shewry, P.R.; Hey, S.J. The contribution of wheat to human diet and health. Food Energy Secur. 2015, 4, 178-202. [CrossRef] [PubMed]

3. Joye, I.J. Dietary Fibre from Whole Grains and Their Benefits on Metabolic Health. Nutrients 2020, 12, 3045. [CrossRef]

4. Mansour, E.; Merwad, A.M.A.; Yasin, M.A.T.; Abdul-Hamid, M.I.E.; El-Sobky, E.E.A.; Oraby, H.F. Nitrogen use efficiency in spring wheat: Genotypic variation and grain yield response under sandy soil conditions. J. Agric. Sci. 2017, 155, 1407. [CrossRef]

5. Hickey, L.T.; Hafeez, A.N.; Robinson, H.; Jackson, S.A.; Leal-Bertioli, S.C.; Tester, M.; Gao, C.; Godwin, I.D.; Hayes, B.J.; Wulff, B.B. Breeding crops to feed 10 billion. Nat. Biotechnol. 2019, 37, 744-754. [CrossRef] [PubMed]

6. Khadka, K.; Raizada, M.N.; Navabi, A. Recent progress in germplasm evaluation and gene mapping to enable breeding of drought-tolerant wheat. Front. Plant Sci. 2020, 11, 1149. [CrossRef]

7. Adrees, M.; Khan, Z.S.; Ali, S.; Hafeez, M.; Khalid, S.; Ur Rehman, M.Z.; Hussain, A.; Hussain, K.; Chatha, S.A.S.; Rizwan, M. Simultaneous mitigation of cadmium and drought stress in wheat by soil application of iron nanoparticles. Chemosphere 2020, 238, 124681. [CrossRef] [PubMed]

8. Nawaz, M.A.; Chung, G. Genetic Improvement of Cereals and Grain Legumes. Genes 2020, 11, 1255. [CrossRef] [PubMed]

9. Ahmad, T.; Kumar, A.; Pandey, D.; Prasad, B. Correlation and path coefficient analysis for yield and its attributing traits in bread wheat (Triticum aestivum L. em Thell). J. Nat. Appl. Sci. 2018, 10, 1078-1084. [CrossRef]

10. Gegas, V.C.; Nazari, A.; Griffiths, S.; Simmonds, J.; Fish, L.; Orford, S.; Sayers, L.; Doonan, J.H.; Snape, J.W. A genetic framework for grain size and shape variation in wheat. Plant Cell 2010, 22, 1046-1056. [CrossRef] [PubMed]

11. Sonmezoglu, O.A.; Bozmaz, B.; Yildirim, A.; Kandemir, N.; Aydin, N. Genetic characterization of Turkish bread wheat landraces based on microsatellite markers and morphological characters. Turk. J. Biol. 2012, 36, 589-597.

12. Kumbhar, S.D.; Kulwal, P.L.; Patil, J.V.; Sarawate, C.D.; Gaikwad, A.P.; Jadhav, A.S. Genetic diversity and population structure in landraces and improved rice varieties from India. Rice Sci. 2015, 22, 99-107. [CrossRef]

13. Najaphy, A.; Parchin, R.A.; Farshadfar, E. Comparison of phenotypic and molecular characterizations of some important wheat cultivars and advanced breeding lines. Aust. J. Crop Sci. 2012, 6, 326. 
14. Ahmadi, M.; Farshadfar, E.; Veisi, S. Evaluation of genetic diversity in land races of bread wheat under irrigated and rainfed conditions. Int. J. Agric. Crop Sci. 2012, 4, 1627-1636.

15. Mansour, E.; Moustafa, E.S.; Qabil, N.; Abdelsalam, A.; Wafa, H.A.; El Kenawy, A.; Casas, A.M.; Igartua, E. Assessing different barley growth habits under Egyptian conditions for enhancing resilience to climate change. Field Crop. Res. 2018, 224, 67-75. [CrossRef]

16. Altay, F. Yield stability of some Turkish winter wheat (Triticum aestivum L.) genotypes in the Western Transtional Zone of Turkey. Turk. J. Field Crop. 2012, 17, 129-134.

17. Denčić, S.R.; Mladenov, N.O.; Kobiljski, B.O. Effects of genotype and environment on breadmaking quality in wheat. Int. J. Plant Prod. 2012, 5, 71-82. [CrossRef]

18. Malik, A.H.; Kuktaite, R.; Johansson, E. Combined effect of genetic and environmental factors on the accumulation of proteins in the wheat grain and their relationship to bread-making quality. J. Cereal Sci. 2013, 57, 170-174. [CrossRef]

19. Mikulikova, D.; Masár, S.; Horvathova, V.; Kraic, J. Stability of quality traits in winter wheat cultivars. Czech. J. Food. Sci. 2009, 27, 403-417. [CrossRef]

20. Kong, L.; Si, J.; Zhang, B.; Feng, B.; Li, S.; Wang, F. Environmental modification of wheat grain protein accumulation and associated processing quality: A case study of China. Aust. J. Crop Sci. 2013, 7, 173-181.

21. Miralbes, C. Discrimination of European wheat varieties using near infrared reflectance spectroscopy. Food Chem. 2008, 106, 386-389. [CrossRef]

22. Goesaert, H.; Brijs, K.; Veraverbeke, W.S.; Courtin, C.M.; Gebruers, K.; Delcour, J.A. Wheat flour constituents: How they impact bread quality, and how to impact their functionality. Trends Food Sci. Technol. 2005, 16, 12-30. [CrossRef]

23. Pomeranz, Y. Wheat Chemistry and Technology (edited); American Association of Cereal Chemists: St. Paul, MN, USA, 1964.

24. Hailegiorgis, D.; Mesfin, M.; Genet, T. Genetic divergence analysis on some bread wheat genotypes grown in Ethiopia. J. Cent. Eur. Agric. 2011, 12, 344-352. [CrossRef]

25. Munjal, R. Genetic diversity in bread wheat for heat tolerance. Ekin J. Crop Breed. Genetic. 2017, 3, 60-78.

26. Ahmad, H.M.; Awan, S.I.; Aziz, O.; Ali, M.A. Multivariative analysis of some metric traits in bread wheat (Triticum aestivum L.). Eur. J. Biotechnol. Biosci. 2014, 1, 22-26.

27. Sahar, B.; Ahmed, B.; Naserelhaq, N.; Mohammed, J.; Hassan, O. Efficiency of selection indices in screening bread wheat lines combining drought tolerance and high yield potential. J. Plant Breed. Crop Sci. 2016, 8, 72-86. [CrossRef]

28. Idrissi, O.; Chafika, H.; Nsarellah, N. Comparaison de lignées avancées de lentille sous stress hydrique durant la phase de floraison et formation des gousses. Nat. Technol. 2013, 8, 53A.

29. Abdolshahi, R.; Nazari, M.; Safarian, A.; Sadathossini, T.S.; Salarpour, M.; Amiri, H. Integrated selection criteria for drought tolerance in wheat (Triticum aestivum L.) breeding programs using discriminant analysis. Field Crop. Res. 2015, 174, 20-29. [CrossRef]

30. Eticha, F.; Grausgruber, H.; Berghoffer, E. Multivariate analysis of agronomic and quality traits of hull-less spring barley (Hordeum vulgare L.). J. Plant Breed. Crop Sci. 2010, 2, 81-95. [CrossRef]

31. Marquetti, I.; Link, J.V.; Lemes, A.L.G.; dos Santos Scholz, M.B.; Valderrama, P.; Bona, E. Partial least square with discriminant analysis and near infrared spectroscopy for evaluation of geographic and genotypic origin of arabica coffee. Comput. Electron. Agric. 2016, 121, 313-319. [CrossRef]

32. Das, B.; Nair, B.; Reddy, V.K.; Venkatesh, P. Evaluation of multiple linear, neural network and penalised regression models for prediction of rice yield based on weather parameters for west coast of India. Int. J. Biometeorol. 2018, 62, 1809-1822. [CrossRef] [PubMed]

33. Das, B.; Sahoo, R.N.; Pargal, S.; Krishna, G.; Verma, R.; Chinnusamy, V.; Sehgal, V.K.; Gupta, V.K.; Dash, S.K.; Swain, P. Quantitative monitoring of sucrose, reducing sugar and total sugar dynamics for phenotyping of water-deficit stress tolerance in rice through spectroscopy and chemometrics. Spectrochim. Acta Part A Mol. Biomol. Spectrosc. 2018, 192, 41-51. [CrossRef]

34. Verma, S.P.; Pathak, V.N.; Verma, O.P. Interrelationship between Yield and its Contributing Traits in Wheat (Triticum aestivum L.). Int. J Curr. Microbiol. App. Sci. 2019, 8, 3209-3215. [CrossRef]

35. Abbasi, Z.; Arzani, A.; Majidi, M.M. Evaluation of genetic diversity of sugar beet (Beta vulgaris L.) crossing parents using agro-morphological traits and molecular markers. J. Agric. Sci. Technol. 2014, 16, 1397-1411.

36. Kavithamani, D.; Yuvaraja, A.; Selvi, B. Principal component analysis and grouping of sorghum (Sorghum bicolor L. Moench) gene pool for genetic diversity. Electron. J. Plant Breed. 2019, 10, 1426-1434. [CrossRef]

37. Al-Naggar, A.M.M.; Shafik, M.M.; Musa, R.Y.M. Genetic diversity based on morphological traits of 19 maize genotypes using principal component analysis and GT biplot. Annu. Res. Rev. Biol. 2020, 68-85. [CrossRef]

38. Yan, W.; Kang, M.S. GGE Biplot Analysis: A Graphical Tool for Breeders, Geneticists, and Agronomists; CRC Press: Boca Raton, FL, USA, 2002.

39. Ober, E.S.; Le Bloa, M.; Clark, C.J.; Royal, A.; Jaggard, K.W.; Pidgeon, J.D. Evaluation of physiological traits as indirect selection criteria for drought tolerance in sugar beet. Field Crop. Res. 2005, 91, 231-249. [CrossRef]

40. Yan, W.; Kang, M.S.; Ma, B.; Woods, S.; Cornelius, P.L. GGE biplot vs. AMMI analysis of genotype-by-environment data. Crop Sci. 2007, 47, 643-653. [CrossRef]

41. Lee, S.J.; Yan, W.; Ahn, J.K.; Chung, I.M. Effects of year, site, genotype and their interactions on various soybean isoflavones. Field Crop. Res. 2003, 81, 181-192. [CrossRef] 
42. Badu-Apraku, B.; Akinwale, R.O. Cultivar evaluation and trait analysis of tropical early maturing maize under Striga-infested and Striga-free environments. Field Crop. Res. 2011, 121, 186-194. [CrossRef]

43. Gabriel, K.R. The biplot graphic display of matrices with application to principal component analysis. Biometrika 1971, 58, 453-467. [CrossRef]

44. Yan, W.; Tinker, N.A. Biplot analysis of multi-environment trial data: Principles and applications. Can. J. Plant Sci. 2006, 86, 623-645. [CrossRef]

45. Ilker, E.; Tonk, F.A.; Caylak, O.; Tosun, M.; Ozmen, İ. Assessment of Genotype X Environment Interactions for Grain Yield in Maize Hybrids Using Ammi and GGE Biplot Analyses. Turk. J. Field Crop. 2009, 14, 123-135.

46. Ukalski, K.; Smialowski, T.; Ukalska, J. Yield and stability analysis of oat genotypes using graphical GGE method. Zywn. Nauk. Technol. J. 2010, 17, 127-140. [CrossRef]

47. Ahmadi, J.; Vaezi, B.; Hossein Fotokian, M. Graphical analysis of multi-environment trials for barley yield using AMMI and GGE-biplot under rain-fed conditions. J. Plant Physiol. Breed. 2012, 2, 43-54.

48. Kendal, E. Comparing durum wheat cultivars with genotype $\times$ yield $\times$ trait (GYT) and genotype $\times$ trait (GT) by biplot method. Chil. J. Agric. Res. 2019, 79, 512-522. [CrossRef]

49. Mortazavian, S.M.M.; Nikkhah, H.R.; Hassani, F.A.; Sharif-al-Hosseini, M.; Taheri, M.; Mahlooji, M. GGE biplot and AMMI analysis of yield performance of barley genotypes across different environments in Iran. J. Agric. Sci. Technol. 2014, 16, 609-622.

50. Sayar, M.S.; Han, Y. Determination of seed yield and yield components of grass pea (Lathyrus sativus L.) lines and evaluations using GGE Biplot analysis method. Tartm. Bilimleri. Dergisi. 2015, 21, 78-92. [CrossRef]

51. Kendal, E.; Dogan, Y. Stability of a candidate and cultivars (Hordeum vulgare L.) by GGE biplot analysis of multi environment yield trials in spring barley. Agric. For. 2015, 61, 307-318. [CrossRef]

52. Akcura, M.; Kokten, K.; Akcacik, A.G.; Aydogan, S. Pattern analysis of Turkish bread wheat landraces and cultivars for grain and flour quality. Turk. J. Field Crop. 2016, 21, 120-130. [CrossRef]

53. Oral, E.; Kendal, E.; Dogan, Y. Selection the best barley genotypes to multi and special environments by AMMI and GGE biplot models. Fresen. Environ. Bulletin. 2018, 27, 5179-5187.

54. Kumar, B.; Ruchi, G.M.L.; Upadhyay, A. Genetic variability, diversity and association of quantitative traits with grain yield in bread wheat (Triticum aestivum L.). Asian J. Agric. Res. 2009, 1, 4-6.

55. Bilsborrow, P.; Cooper, J.; Tetard-Jones, C.; Średnicka-Tober, D.; Barański, M.; Eyre, M.; Schmidt, C.; Shotton, P.; Volakakis, N.; Cakmak, I.; et al. The effect of organic and conventional management on the yield and quality of wheat grown in a long-term field trial. Eur. J. Agron. 2013, 51, 71-80. [CrossRef]

56. Steel, R.G. Principles and Procedures of Statistics a Biometrical Approach (No. 519.5 S8); McGraw Hill: New York, NY, USA, 1997.

57. Ullah, I.; Ashraf, M.; Zafar, Y. Genotypic variation for drought tolerance in cotton (Gossypium hirsutum L.): Leaf gas exchange and productivity. Flora-Morphology, Distribution. Funct. Ecol. Plants. 2008, 203, 105-115. [CrossRef]

58. Hintze, J. NCSS and PASS number crucher statistical systems. NCSS Statistical Software: Kaysville, UT, USA, 2001. Available online: http:/ / www.NCSS.com (accessed on 27 August 2021).

59. Frutos, E.; Galindo, M.P.; Leiva, V. An interactive biplot implementation in R for modeling genotype-by-environment interaction. Stochastic Environ. Res. Risk Assess. 2014, 28, 1629-1641. [CrossRef]

60. Yan, W.; Rajcan, I. Biplot analysis of test sites and trait relations of soybean in Ontario. Crop Sci. 2002, 42, 11-20. [CrossRef]

61. Yan, W.; Kang, M.S. GGE Biplot Analysis: A Graphical Tool for Breeders, Geneticists, and Agronomists; CRC Press: Boca Raton, FL, USA, 2003; p. 213.

62. Osekita, O.S.; Ajayi, A.T. Character expression and selection differential for yield and its components in soybean (Glycine max (L.) Merrill). Acad. J. Agric. Res. 2013, 1, 167-171.

63. Drezner, G.; Dvojkovic, K.; Horvat, D.; Novoselovic, D.; Lalic, A. Environmental impacts on wheat agronomic and quality traits. Cereal Res. Commun. 2007, 35, 357-360. [CrossRef]

64. Atkinson, M.D.; Kettlewell, P.S.; Poulton, P.R.; Hollins, P.D. Grain quality in the Broadbalk wheat experiment and the winter North Atlantic oscillation. J. Agric. Sci. 2008, 146, 541. [CrossRef]

65. Xie, Q. Physiological and Genetic Determination of Yield and Yield Components in a Bread Wheat $\times$ Spelt Mapping Population. Doctoral Dissertation, University of Nottingham, Nottingham, UK, 2015.

66. ALIU, S.A.; Fetahu, S. Determination on genetic variation for morphological traits and yield components of new winter wheat (Triticum aestivum L.) lines. Not. Sci. Biol. 2010, 2, 121-124. [CrossRef]

67. Shinwari, Z.K.; Rehman, H.I.N.A.; Rabbani, M.A. SDS-Page based genetic divergence in safflower (Carthamus Tinctorius L.). Pak. J. Bot. 2014, 46, 811-815.

68. Singh, M.K.; Sharma, P.K.; Tyagi, B.S.; Singh, G. Genetic analysis for morphological traits and protein content in bread wheat (Triticum aestivum L.) under normal and heat stress environments. Indian J. Genet. Plant Breed. 2013, 73, 320-324. [CrossRef]

69. Singh, G.; Kulshreshtha, N.; Singh, B.N.; Setter, T.L.; Singh, M.K.; Saharan, M.S.; Tyagi, B.S.; Verma, A.; Sharma, I. Germplasm characterization, association and clustering for salinity and waterlogging tolerance in bread wheat (Triticum aestivum). Indian J. Agric. Sci. 2014, 84, 1102-1110.

70. Sabaghnia, N.; Janmohammadi, M.; Bashiri, A.; Asghari-Shirghan, R. Genetic variation of several bread wheat (Triticum aestivum L.) genotypes based on some morphological traits. Agron. Sci. 2014, 69, 44-54. 
71. Jaiswal, J.P. Genetic Diversity Analysis in Exotic Germplasm Accessions of Bread Wheat (Triticum aestivum L.) by Cluster Analysis. Electron. J. Plant Breed. 2015, 6, 1111-1117.

72. Kumar, P.; Singh, G.; Kumar, S.; Kumar, A.; Ojha, A. Genetic analysis of grain yield and its contributing traits for their implications in improvement of bread wheat cultivars. J. Nat. Appl. Sci. 2016, 8, 350-357. [CrossRef]

73. Jan, S.A.; Shinwari, Z.K.; Rabbani, M.A. Morpho-biochemical evaluation of Brassica rapa sub-species for salt tolerance. Genetika 2016, 48, 323-338. [CrossRef]

74. Sabaghnia, N.; Behtash, F.; Janmohammadi, M. Graphic analysis of trait relations of spinach (Spinacia oleracea L.) landraces using the biplot method. Acta Univ. Agric. Et Silvic. Mendel. Brun. 2015, 63, 1187-1194. [CrossRef]

75. Verma, P.N.; Singh, B.N.; Singh, G.; Singh, M.K.; Setter, T.L. Genetic diversity analysis for yield and other agronomic traits in bread wheat under water logged sodic soil condition. J. Wheat Res. 2014, 6, 51-58.

76. Vora, Z.N.; Patel, J.B.; Pansuriya, A.G.; Yusufzai, S.A. Genetic divergence analysis in bread wheat (Triticum aestivum L.). Res. Environ. Life Sci. 2017, 10, 291-294.

77. Sheykhi, A.; Pirdashti, H.; Abbasian, A.; Niknejhad, Y. Segregation of some wheat (Triticum aestivum L.) genotypes using cluster analysis procedure. Int. J. Farm Alli. Sci. 2014, 3, 225-229.

78. Gharib, M.A.A.H.; Qabil, N.; Salem, A.H.; Ali, M.M.A.; Awaad, H.A.; Mansour, E. Characterization of wheat landraces and commercial cultivars based on morpho-phenological and agronomic traits. Cereal Res. Commun. 2021, 49, 149-159. [CrossRef]

79. Spanic, V.; Cosic, J.; Zdunic, Z.; Drezner, G. Characterization of Agronomical and Quality Traits of Winter Wheat (Triticum aestivum L.) for Fusarium Head Blight Pressure in Different Environments. Agronomy 2021, 11, 213. [CrossRef]

80. Meena, N.; Mishra, V.K.; Baranwal, D.K.; Singh, A.K.; Rai, V.P.; Prasad, R.; Arun, B.; Chand, R. Genetic evaluation of spring wheat (Triticum aestivum L.) recombinant inbred lines for spot blotch (Bipolaris Sorokiniana) resistance and yield components under natural conditions for South Asia. J. Agric. Sci. Technol. 2014, 16, 1429-1440.

81. Bhanupriya, B.; Satyanarayana, N.; Mukherjee, S.; Sarkar, K. Genetic diversity of wheat genotypes based on principal component analysis in Gangetic alluvial soil of West Bengal. J. Crop Weed. 2014, 10, 104-107.

82. Ali, M.A.; Zulkiffal, M.; Anwar, J.; Hussain, M.; Farooq, J.; Khan, S.H. Morpho-physiological diversity in advanced lines of bread wheat under drought conditions at post-anthesis stage. J. Anim. Plant Sci. 2015, 25, 431-441.

83. Yan, W.; Tinker, N.A. An integrated system of biplot analysis for displaying, interpreting, and exploring genotype-by-environment interactions. Crop Sci. 2005, 45, 1004-1016. [CrossRef]

84. Hagos, H.G.; Abay, F. AMMI and GGE biplot analysis of bread wheat genotypes in the northern part of Ethiopia. J. Plant Breed. Genet. 2013, 1, 12-18.

85. Stanisavljević, D.; Mitrović, B.; Mirosavljević, M.; Ćirić, M.; Čanak, P.; Stojaković, M.; Ivanović, M. Identification of the most desirable maize testing environments in northern Serbia. Ratar. I Povrt. /Field Veg. Crop. Res. 2013, 50, $28-35$.

86. Adjabi, A.; Bouzerzour, A.; Benmahammed, A. Stability analysis of durum wheat (Triticum durum Desf.) grain yield. J. Agron. 2014, 13, 131-139. [CrossRef]

87. Dogan, Y.; Kendal, E.; Oral, E. Identifying of relationship between traits and grain yield in spring barley by GGE Biplot analysis. Agri. For./Poljopr. I Sumar. 2016, 62, 239-252. [CrossRef]

88. Karami, E.; Arshadi, A.; Sartip, A.; Zare, M.; Rezabakhsh, P. Genotypes performance in relation to drought tolerance in barley using multi-environment trials. Agron. Res. 2018, 16, 5-21.

89. Oury, F.X.; Godlin, C. Yield and grain protein concentration in bread wheat: How to use the negative relationship between the two characters to identify favorable genotypes? Euphytica 2007, 157, 45-57. [CrossRef]

90. Tayyar, S. Variation in grain yield and quality of Romanian bread wheat varieties compared to local varieties in northwestern Turkey. Rom. Biotechnol. Lett. 2010, 15, 5189-5196.

91. Peterson, D.M.; Wesenberg, D.M.; Burrup, D.E.; Erickson, C.A. Relationships among agronomic traits and grain composition in oat genotypes grown in different environments. Crop Sci. 2005, 45, 249-255. [CrossRef]

92. Kendal, E.; Sayar, M.S. The stability of some spring triticale genotypes using biplot analysis. J. Anim. Plant Sci. 2016, 26, 754-765.

93. Yan, W.; Frégeau-Reid, J. Genotype by Yield* Trait (GYT) Biplot: A Novel Approach for Genotype Selection based on Multiple Traits. Sci. Rep. 2018, 8, 1-10. [CrossRef]

94. Baljani, R.; Shekari, F.; Sabaghnia, N. Biplot analysis of trait relations of some safflower (Carthamus tinctorius L.) genotypes in Iran. Crop Res. 2015, 50, 63-73.

95. Paramesh, M.; Reddy, D.M.; Priya, M.S.; Sudhakar, P.S.P.; Reddy, K.H.P. GT biplot analysis for yield and drought related traits in mung bean (Vigna radiata L. Wilczek). Electron. J. Plant Breed. 2016, 7, 538-543. [CrossRef]

96. Kendal, E. Evaluation of some barley genotypes with genotype by yield* trait (GYT) biplot method. Agri. For./Poljopr. I Sumar. 2020, 6, 137-150.

97. Xu, N.; Fok, M.; Li, J.; Yang, X.; Yan, W. Optimization of cotton variety registration criteria aided with a genotype-by-trait biplot analysis. Sci. Rep. 2017, 7, 17237. [CrossRef]

98. González, A.M.; Monteagudo, A.B.; Casquero, P.A.; De Ron, A.M.; Santalla, M. Genetic variation and environmental effects on agronomical and commercial quality traits in the main European market classes of dry bean. Field Crop. Res. 2006, 95, 336-347. [CrossRef]

99. Mohammadi, R.; Amri, A. Graphic analysis of trait relations and genotype evaluation in durum wheat. J. Crop Improv. 2011, 25, 680-696. [CrossRef] 
100. Dolatabad, S.S.; Choukan, R.; Hervan, E.M.; Dehghani, H. Multi-environment analysis of traits relation and hybrids comparison of maize based on the genotype by trait biplot. Am. J. Agric. Biol. Sci. 2010, 5, 107-113. [CrossRef]

101. Samonte, S.O.P.; Tabien, R.E.; Wilson, L.T. Parental selection in rice cultivar improvement. Rice Sci. 2013, 20, 45-51. [CrossRef] 